\title{
Sosyal Bilgiler Öğretmenlerinin Demokrasiye İlişkin Algılarının Metafor Aracılığıyla İncelenmesi
}

\author{
Fatma SUSAR KIRMIZI \\ Pamukkale Üniversitesi \\ fsusar@pau.edu.tr \\ ORCID ID: 0000-0002-0426-1908 \\ Özge TARHAN \\ Pamukkale Üniversitesi \\ ocinar@pau.edu.tr \\ ORCID ID: 0000-0003-0783-6962
}

\begin{tabular}{l} 
Araştırma Makalesi \\
\hline Geliş Tarihi: 30.12 .2019
\end{tabular}

\section{Atıf Bilgisi}

Susar Kırmızı, F. ve Tarhan, Ö. (2020). Sosyal Bilgiler öğretmenlerinin demokrasiye ilişkin algılarının metafor aracılığıyla incelenmesi. Ahi Evran Üniversitesi Sosyal Bilimler Enstitüsü Dergisi, 6(3), 760-779.
DOI: $10.31592 /$ aeusbed.667755

Revize Tarihi: 21.10 .2020

Kabul Tarihi: 23.10 .2020

\section{ÖZ}

Demokrasi günümüzde yalnızca devlet yönetiminde değil yaşamın her alanında önemli bir değer olarak görülmektedir. $\mathrm{Bu}$ araştırmanın amacı sosyal bilgiler öğretmenlerinin demokrasi kavramına ilişkin sahip oldukları metaforlar ile bu metaforların ortak özellikler bakımından hangi kavramsal kategoriler altında toplandığını tespit etmektir. Çalışmada, nitel araştırma yöntemlerinden fenomenoloji benimsenmiştir. Metaforların ve temaların belirlenmesinde ise ve içerik analizinden yararlanılmıştır. Verilerin elde edilmesinde araştırmacılar tarafından hazırlanmış olan form kullanılmıştır. Araştırmada çalışma grubunun belirlenmesinde maksimum çeşitlilik örnekleme yönteminden yararlanılmıştır. 2015-2016 öğretim yılının bahar döneminde, yapılan araştırmaya, Denizli il merkezinde, alt, orta ve üst sosyo-ekonomik düzeydeki okullarda görev yapan ve tesadüfi yöntemle seçilen 36 ortaokuldan toplam 143 sosyal bilgiler öğretmeni katılmıștır. Öğretmenler en çok "farklılıkları kabul etme" (25 kişi, \% 17,48) ve "demokrasinin eşitlikçi yanı" (25 kişi, \% 17,48) temalarında metaforlar ortaya koymuşlardır. Bu metaforlarda demokrasinin insan ilişkileri üzerindeki olumlu ve kolaylaştırıcı etkileri ile insanlar arasındaki eşitliği sağlamada ne kadar etkili olduğu dile getirilmiştir. En az metafor üretilen tema ise "engelleri aşmadır" (5 kişi, \% 3,49). Bu tema kapsamındaki metaforlarda gerçekleştirilmesi zor olan durumlara vurgu yapılmış ve demokrasinin toplumda yerleşmesinin zorluğu dile getirilmiștir. Araștırma sonucunda elde edilen metaforlar, demokrasi kavramının sosyal bilgiler öğretmenleri tarafından nasıl algılandığını belirlemek amacıyla güçlü birer ipucu özelliği taşımaktadır.

Anahtar kelimeler: Demokrasi, metafor, Sosyal Bilgiler öğretmeni.

\section{An Analysis of Social Studies Teachers' Perceptions of Democracy through Metaphor}

\section{ABSTRACT}

Today, democracy is seen as an important value not only in the administration of the state but also in all areas of life. The aim of this study is to determine the metaphors that social studies teachers have about the concept of democracy and what conceptual categories these metaphors are collected in terms of common characteristics. Phenomenology, one of the qualitative research methods, was adopted in the study. Metaphors and themes were determined and content analysis was used. The form prepared by the researchers was used to obtain the data. Maximum diversity sampling method was used to determine the study group. In the spring semester of 2015-2016 academic year, a total of 143 social studies teachers from randomly selected 36 secondary schools, who were employed in lower, middle and upper socio-economic schools in Denizli city center, participated in the study. Teachers mostly metaphors on the theme of "accepting differences" ( 25 people, $17.48 \%$ ) and "egalitarian side of democracy" (25 people, $17.48 \%)$. In these metaphors, the positive and facilitating effects of democracy on human relations and how effective it is in ensuring equality between people are stated. The theme with the least metaphor is mad "overcoming obstacles" ( 5 people, $3.49 \%$ ). The metaphors within the scope of this theme emphasized the difficult situations to be realized and expressed the difficulty of establishing democracy in society. The metaphors obtained as a result of the research are strong clues to determine how the concept of democracy is perceived by social studies teachers.

Key words: Democracy, metaphor, Social Studies teacher. 


\section{Giriş}

Demokrasi kavramının ilk olarak ortaya çıtı̆̆ 1 dönemden itibaren demokrasinin tanımlamasına yönelik birçok tanımlama yapılmıştır. Halkın kendi kendini yönetmesi anlamına gelen demokrasinin günümüze kadar birçok tanımı yapılmıştır. Lipset'e (1986) göre demokrasi, nüfusun genişçe bir kısmının, iktidar için yarışanlar arasından bir seçim yaparak önemli kararların alınmasında etkili olunmasına izin veren sosyal bir mekanizmadır. Bununla birlikte demokrasi kavramına ilişkin birbirinden farklı tanımlar bulunmaktadır. Örneğin Öncül (2000) demokrasi, bireye değer veren ve insan kişiliğinin bütünlüğünü önemli sayan, birlikte yaşayan insanların birbiriyle karşılıklı ilişkilerinde saygı ve işbirliği, hoşgörü ve doğruluk gibi nitelikleri yansıtan, toplumsal ilişkilere yön veren bir yaşam biçimi olarak tanımlarken, Yetek'e (2003) demokrasiyi, halkın yönetime kendi iradesi 1şığında seçimler yoluyla katılabilmesini sağlayan, bunun yanı sıra da sadece çoğunluğun egemenliğini sağlayan bir sistem olmayıp, çoğulcu bir anlayışla azınlıkta kalan düşüncelerin de yaşayabilmesine imkân veren, bu düşüncedeki bireylere sahip çıkan ve bu bireyleri koruyan bir sistem olarak tanımlamıştır. Beetham'a (2006) “ortak kararlara toplumda bulunan tüm azınlıklarla birlikte eşit katılım" Bellamy (1991) ise demokrasiyi, halkın kendisini yönetecek bireyleri kabul etme ya da reddetme hakkına sahip olması olarak nitelendirmişlerdir. Tüm bu tanımlardan yola çıkarak demokrasiyi çoğunluğun egemenliğinin hüküm sürmesinin yanı sıra azınlıkta bulunan, karşıt düşünceye sahip kitlelerin de haklarına saygı duyulduğu, kendilerini ifade etmesine izin verildiği bir yaşam biçimi olarak tanımlayabiliriz.

Cumhuriyetin başlarında Türk eğitimi hakkında bir rapor hazırlayan J. Dewey Türkiye'nin demokratikleşmesinin temelini okullarda demokratik yolla yapılan eğitim ve öğretim uygulamalarının oluşturacağını vurgulamıştır (Akt.; Karadağ, Yalçın, Baloğlu, 2006, s. 65). Topluma demokrasi bilincinin yerleşmesi için eğitimin demokrasi kültürünü yaşatan bir süreç olması, temel eğitimden itibaren toplumsal değerlerin kazandırılarak sosyal birlik ve bütünleşmenin sağlanması gerekmektedir. Demokrasi bilinci küçük yaşlardan itibaren kazandırılmalıdır. Ailede kazanılan demokrasi bilinci ancak okulda verilen eğitimle gelişip, bir yaşam biçimine dönüşebilir. Okullar ise gelecek nesilleri demokrasiye hazırlamada etkili rol oynayan yerlerdir. Okullar öğrencilerin temel bilgileri öğrenmelerinin yanı sıra toplumda var olan kültür ve geleneklerin öğrencilere öğretilmesinde önemli bir yere sahiptir (Beetham ve Boyle, 1998; Soydaş ve Güven, 2009; Westheimer ve Kahne, 2000). O'Hair, McLaughlin ve Reitzug'e (2000) göre demokrasi eğitiminin öğrencilere verilmesi sürecinde okullaşmanın ana amacının öğrencileri gerçek yaşama hazırlamak, onlara toplumsal yaşam becerileri kazandırmak ve toplumsal yaşama uyum sağlayacak olan bireylerin de okullarda yapılacak demokrasi eğitiminin öğretimine dayalı etkinlerle demokrasiyi daha iyi kavrayacaklarını bildirmektir. Touraine'e (2004) göre farklı ortamlardan gelen gençlerin ve azınlıkta olanların ulusal düşünceyi, hoşgörüyü paylaşmasının ve özgürlük kavramının ne anlama geldiğini anlamasının o ülke bireylerine demokrasi bilincinin yerleşmesi bakımından önemlidir. Bu sebepledir ki okullarda demokrasi uygulamaları toplumun her kesiminden gelen öğrencilerin demokrasiyi öğrenmeleri, demokratik davranış geliştirmelerini sağlayacak biçimde düzenlenmelidir. Engle ve Ochoa'ya (1988) göre, öğrencilere eğitim hayatları süresince derslerde kültürel farklılıklardan kaynaklanan sorunlara hoşgörüyle yaklaşma, adalet, eşitlik, özgürlük ve sabır gibi temel değerler öğretilmesi gerektiğini ve bunu yaparken de yaşadığı toplumda ve dünyadaki önemli gelişmelere duyarsız kalmamasını sağlamayı, toplumlarda yaşanan sorunları gerekçeleriyle farkına varmalarını sağlamak gerektiğini vurgulamıştır. Toplumu oluşturan bireylerin birbirini kabullenmeleri ve birbirlerine saygı göstermeleri demokrasi kültürünün dokunulmaz unsurlarındandır (Taşkesen, 2005, s. 111). Günlük yaşamlarında temel insan haklarını kullanamayan bireylerin demokrasiyi içselleştirebilmekte zorlandığı, demokrasinin yalnızca teoride tanım olarak ya da ülkelerinin yönetim biçimi olarak hafizalarında kaldığ 1 görülmektedir. $\mathrm{Bu}$ bağlamda, temel insan hakları olan ifade özgürlüğü, fırsat eşitliği, anadilini kullanma ve öğrenme hakk1, gösteri ve örgütlenme özgürlüğü, propaganda yapma özgürlüğü, baskıya uğramama hakkı gibi temel hakların günlük yaşamda da uygulamalarının yapılması ülkelerde demokrasi kültürünün yerleşmesi ve bireylerin demokrasiyi içselleştirebilmeleri açısından son derece önemlidir (Yağan, 2010, ss. 5-6). 
"Demokrasi Eğitimi” ilkesi çerçevesinde öğrencilere demokrasi bilincini aşılamak amaciyla öğretmenlere büyük sorumluluklar düşmektedir. Öğretmenler sahip oldukları demokratik özellikleriyle öğrencilerine model olurlar. Demokratik değerleri bir yaşam biçimine dönüştürmüş öğretmenler okul ortamı içerisinde davranışları ile bunu yaşatırlar (Çankaya ve Seçkin, 2004, s. 462). Demokratik bir öğretmen öğrenci ile girdiği iletişimi sadece bir öğrenme ve öğretme etkinliği olarak ele almamalıdır. Sınıf ortamındaki iletişim, öğrenme ve öğretme etkinliğinden öte öğrencinin benlik bilincinin gelişmesine olumlu katkı sağlamak, özne birey olarak varlığının değerinin farkına vardırmak ve bu süreçlerin doğal bir uzantısı olarak bağımsız düşünme alışkanlığını kazandırmak gibi çok önemli işlevlere sahiptir (Akt.; Kuş, Sönmez ve Karatekin, 2011). Demokrasi, bir yönetim şekli olmaktan öte, toplumda ortak yaşama biçimi olarak algılanmalı ve okullar da birer demokratik örgüt olarak görülmelidir (Dewey, 2010). Okullar çocuklara toplumun en önemli öğesi olduklarını hissettirmelidir (Maitles ve GilChrist, 2006). Çocukların demokratik değerlere uygun bir biçimde yetiştirilebilmeleri için demokrasiye ilişkin bilgi, beceri ve tutumları kazanmaları ve bunları içselleştirmeleri adına okullarda demokrasi eğitimine önem vermek gerekir (Farrel, 1998). Yaşam boyu demokrasi benimsemiş bireyler yetiştirmek için eğitim sisteminde öğretmenlerin üzerine düşen önemli görevlerden biri de çocuklara demokrasiyle ilgili temel bilgi, beceri, değerler ve davranışları öğretmektir. Bu nedenle, erken yaşlar çocukları demokrasinin gerekleriyle tanıştırmanın en ideal yaşlarıdır.

Demokrasi eğitiminin daha etkili bir şekilde yapılması için resmî kurumların yanı sıra sivil kuruluşların çalışma ve katkıları büyük önem taşımaktadır. Eğitim ile sivil toplum kuruluşları arasındaki ilişki incelendiğinde, Sivil Toplum Örgütlerinde aktif rol oynayan bireyler, bireysel çıkarlarını göz ardı etmeyi ve toplumsal sorunları fark etmeyi öğrenir ve bu sorunlara ilişkin çözüm üretme sürecine dâhil olmanın önemini kavrarlar (Tarhan, 2016). Sivil toplum örgütleri demokrasi eğitimi içerisinde önemli bir yer tutmaktadır. Çünkü demokrasi kültürünün ve demokratik yaşam bilincinin gelişmesinde, bu organizasyonlar oldukça etkilidir. Demokrasi eğitimi sürecinde Sivil Toplum Kuruluşları öğrencilerin demokratik süreci anlamalarını kolaylaştıran ve bu sürece dâhil olmaları konusunda öğrencileri istekli kılan demokratik toplumların vazgeçilmez unsurlarından biri sayılabilir (Kuş ve Tarhan, 2016). Bu sebeple bir toplumda demokrasi kültürünün benimsenmesi ve etkili vatandaş yetiştirilmesi açısından sivil toplum kuruluşlarının önemi oldukça büyüktür.

Metaforlar, kişisel değerleri önyargısız bir şekilde göstermeleri bakımından önemlidir (Richardson, 2003, s. 56). Bu açıdan bakıldığında bireylerin oluşturduğu metaforlar bireyi rahatsız eden sorunları ve o kavramın bireyde uyandırdığı duyguyu ortaya çıkarmak açısından önemli bir firsattır. Metaforlar, fikir köprüleridir ki bunlar bir fikri başka bir şekilde ifade etmemiz, yerine başka bir şey bulmamız için belleği sorgulamamıza izin verir. Lakoff ve Johnson'a (2010) göre metafor, nesnelere soyut ya da somut olarak bir şekil vermenin yanı sıra kendimizi ve dış dünyayı nasıl algıladığımızı anlatan araçlardır. Cameron'a (1996) göre metaforlar; toplumlar ve kişiler için öğrenmede ve var olan bilgilerin yeniden yapılandırılmasında etkilidir. Palmquist (2001), birbirinden farklı düşünce ve kavram arasında bağ kurulması şeklinde metaforu tanımlayarak, metafor oluşturmanın imgeler aracılı̆̆ıyla ilişki veya bağ kurmadan meydana geldiğini önemle vurgulamıştır. $\mathrm{Bu}$ nedenle demokrasi değerinin metafor aracilığıyla incelenmesi, öğretmenlerin demokrasi değerine bakış açısını ortaya koymak için zihinlerinde oluşturdukları imgelerin neler olduğunu tespit etmek bakımından önemlidir. Metaforlar akılda kalıcılığı ve bir olgunun daha iyi anlatımı için önemli bir ifade biçimidir. Demokratik biçimde davranmayı metofor biçiminde ifade eden öğretmenlerin öğrencilerde demokrasi bilinicini geliştirmesinde önemli bir katkısı bulunabilir.

$\mathrm{Bu}$ araştırmanın amacı Sosyal Bilgiler öğretmenlerinin demokrasi kavramına ilişkin sahip oldukları zihinsel imgeleri metaforlar aracılığıyla ortaya çıkartmaktır. Bu amaç çerçevesinde şu soruya yanıt aranmıştır: Sosyal bilgiler öğretmenlerinin demokrasi kavramına ilişkin sahip oldukları metaforlar (zihinsel imgeler) nelerdir? 


\section{Yöntem}

Sosyal Bilgiler öğretmenlerinin demokrasi kavramına ilişkin zihinsel imgelerini açıklamada kullandıkları metaforları tespit etmeyi amaçlayan bu çalışma, betimsel tarama modelinde nitel bir araştırmadır. Araştırmada nitel araştırma yöntemleri desenlerinden biri olan olgubilim deseni kullanılmıştır. Olgubilim (fenomenoloji) deseni gündelik hayatta farkında olduğumuz ancak derinlemesine ve ayrıntılı bir fikir geliştirmediğimiz olgulara odaklanmaktadır (Patton, 2002, s. 105). Metaforlar çalışılan konuya ilişkin sağlam ve zengin bir veriler sunma konusunda oldukça yararlıdır (Yıldırım ve Şimşek, 2006, s. 212). Schmitt (2005, s. 356) özellikle nitel araştırmalarda ortaya çıkan karmaşı bilgilerin açık ve net olarak algılanmasında metaforların önemli işlevleri olduğunu belirtmektedir. Bu araştırmada da ortaokullarda görev yapmakta olan sosyal bilgiler öğretmenlerinin demokrasi kavramına yönelik algıları metaforlar aracılığıyla incelenmeye çalışılmıştır.

\section{Çalışma Grubu}

Araştırma Denizli il merkezinde ortaokullarda görev yapan sosyal bilgiler öğretmenleri ile gerçekleştirilmiştir. Katılımcıların belirlenmesinde maksimum çeşitlilik örnekleme yönteminden yararlanılmıştır. Denizli merkez ilçedeki ortaokullar alt, orta ve üst sosyo-ekonomik gruba ayrılmış her gruptan 12 olmak üzere toplam 36 ortaokul belirlenmiştir. Çalışma 143 Sosyal Bilgiler öğretmeninin katılımıyla gerçekleşmiştir. Öğretmenlerden 90’’1 (\% 62,93) kadın, 53’ü $(\%$ 37,06) erkektir.

\section{Veri Toplama Aracı}

Veri toplama aracı olarak demokrasi kavramına ilişkin sahip oldukları (metaforları) belirlemek için katılımcıların "Demokrasi... a/e benzer; çünkü ............." cümlesini tamamlamaları istenmiştir. Yıldırım ve Şimşek'e (2006) göre, her birey aynı mecaza (metafora) farklı anlamlar yükleyebilmektedir. Bu çalışmada da öğretmenlerin yazmış oldukları metaforları niçin ürettiklerini görmek amacıyla “çünkü” ifadesinden sonraki boşluğa açıklama yazmaları istenmiştir.

\section{Verilerin Analizi}

Verilerin çözümlenmesinde içerik analizi ve ona bağlı olarak kategorisel analize başvurulmuştur. $\mathrm{Bu}$ çalışmada da güvenirlik analizleri çerçevesinde öğretmenlerin demokrasi kavramına yönelik geliştirdikleri metaforlardan benzer içerikli olanlar bir araya getirilmiş kendi içinde sınıflandırılmıştır. Kavramsal kategorilerin oluşturulmasında da her iki araştırmacının tespitleri karşılaştırılmış daha sonra da tutarlılık düzeyi tespit edilmeye çalışılmıştır. Miles ve Huberman'ın (1994, s. 64) formülü (Güvenirlik=görüş birliği/görüş birliği+görüş ayrilığ1 X 100) kullanılarak yapılan tutarlılık analizi sonucunda oranın \%94 olduğu tespit edilmiştir. Miles ve Huberman'a (1994) göre iki araştırmacı tarafından yapılan sınıflandırmaların karşılaştırılmasında yüzde 90 ve üzeri tutarlılığın sağlanması, çalışmanın güvenirliğini arttırmaktadır.

\section{Bulgular}

$\mathrm{Bu}$ bölümde katılımcıların demokrasi kavramına ilişkin geliştirdikleri metaforlar ve bu metaforların sınıflandırılması sonucu ortaya çıkan temalara yer verilmiştir. Metaforlar, gerekçeleri ve temalar tablolar halinde sunulmuş ve tabloların hemen sonrasında yorumlara yer verilmiştir. Araştırma kapsamında elde edilen temalar "yaşamın olmazsa olmazı, engelleri aşma, ideal demokrasi anlayışı, farklılık ve empati, demokrasinin topluma kazandırdıkları, farklılıkları kabul etme, demokrasinin eşitlikçi yanı, demokrasinin özgürlükçü yanı, demokrasi ve toplumsal huzur, demokrasinin gelişim süreci ve sıra dışı benzetmeler" şeklindedir. Öğretmenlerin "Yaşamın Olmazsa Olmazı" temasında ortaya koydukları metaforlar ve gerekçelerinden örnekler Tablo 1'de verilmiştir. 
Tablo 1

Yaşamın Olmazsa Olmazı Temasına İlişkin Metaforlar ve Gerekçeleri

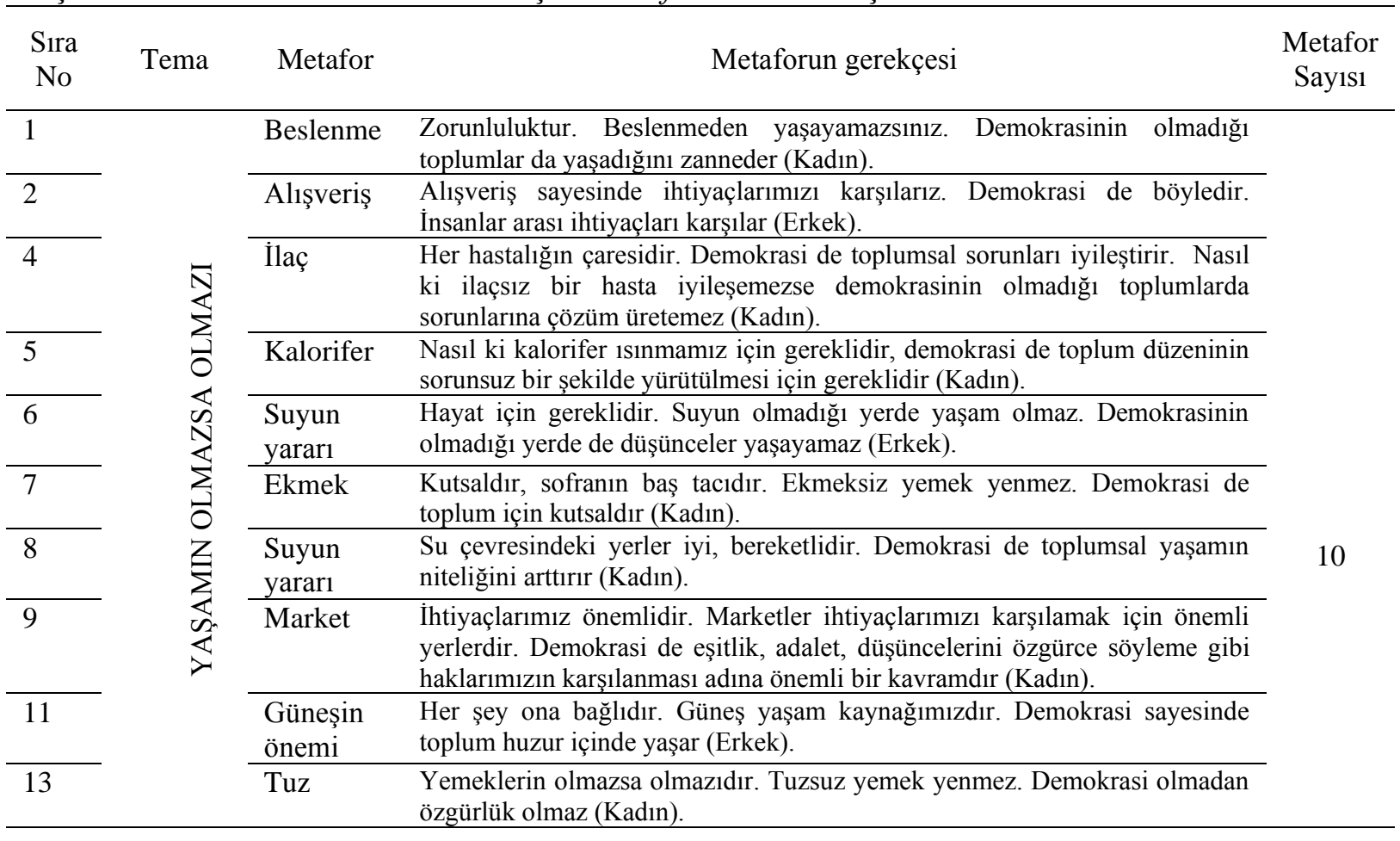

Tablo 1'deki veriler incelendiğinde 13 öğretmenin $(\% 9,09)$ "yaşamın olmazsa olmazı" temas1 altında 10 ayrı metafor geliştirdiği görülmektedir. Bu tema altında yer alan metaforlarda demokrasinin gerekliliği, önemi ve toplumsal açıdan vazgeçilmezliği vurgulanmaktadır. Vurgular yapılırken de insanların yaşamını sürdürmesi için gerekli olan nesne ve durumlara yönelik benzetmeler yapılmıştır. Geliştirilen metaforların gerekçelerine bakıldığında öğretmenler demokrasiyi temel bir gereksinim olarak görmekte dahası yaşamsal bir öneme sahip olduğunu dile getirmektedir. İnsanlar su, ekmek, güneş, 1sınma vb. olmadan yaşayamaz. Bunlar temel biyolojik gereksinimlerdir. Örneğin suyun olmadığı bir ortamda hiçbir canlının yaşaması olası değildir ya da tedavi edilmeyen bir hastalık insanı ölüme kadar götürebilir. Öğretmenler bu yaşamsal gereksinimlerden yola çıkarak demokrasinin ne kadar önemli olduğunu anlatmaya çalışmıştır. Öğretmenlere göre sosyal ve siyasal düzenin devamlılı̆̆ için demokrasi şarttır. Demokratik bireyleri öğretmenlerin yetiştireceği göz önüne alındığında ortaya çıkan bu tespit oldukça manidardır. Buna bağlı olarak katılımcıların demokrasinin önemine ilişkin olarak belirgin bir farkındalığa sahip olduğu da söylenebilir. Tablo 2'de öğretmenlerin "Engelleri Aşma" temasında geliştirmiş oldukları metaforlar ve gerekçelerinden örnekler görülmektedir.

Tablo 2

Engelleri Aşma Temasına İliş̧kin Metaforlar ve Gerekçeleri

\begin{tabular}{|c|c|c|c|c|}
\hline $\begin{array}{l}\text { Sira } \\
\text { No }\end{array}$ & Tema & Metafor & Metaforun gerekçesi & $\begin{array}{c}\text { Metafor } \\
\text { Sayısı }\end{array}$ \\
\hline 14 & \multirow{5}{*}{ 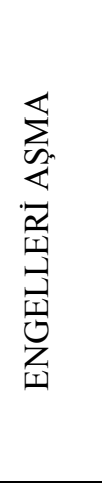 } & $\begin{array}{l}\text { Ders } \\
\text { çalışmak }\end{array}$ & $\begin{array}{l}\text { Çünkü zordur. Ders çalışmayı sevmiyorum. Genel olarak öğrenciler ders } \\
\text { çalışmayı angarya olarak görürler (Kadın). }\end{array}$ & \multirow{5}{*}{5} \\
\hline 15 & & Öğrenme & $\begin{array}{l}\text { Öğrenmek zordur. Zaman ve çaba ister. Demokrasinin de topluma } \\
\text { yerleşmesi zordur (Erkek). }\end{array}$ & \\
\hline 16 & & Hakem & $\begin{array}{l}\text { Ne olursa olsun yansız olup o kadar insana sabır göstermek zordur. } \\
\text { Demokratik tavrın sergilenmesi de kolay bir şey değildir (Erkek). }\end{array}$ & \\
\hline 17 & & Sur & $\begin{array}{l}\text { Surları aşıp hedefe ulaşmak zordur ama. Surlar engelleri meydana getirir. } \\
\text { Bir toplumda demokrasinin tam olarak yerleşmesi için de birçok engeli } \\
\text { aşması gerekebilir (Kadın). }\end{array}$ & \\
\hline 18 & & Matematik & $\begin{array}{l}\text { Matematiği öğrenmek de öğretmek de diğer derslere oranla zordur. } \\
\text { Yatkınlık yoksa öğrenmek büyük çaba gerektirir. Demokrasi kültürü } \\
\text { gelişmemiş toplumlarda da bu kavramı oluşturmak o kadar zordur işte } \\
\text { (Kadın). }\end{array}$ & \\
\hline
\end{tabular}


Tablo 2'deki veriler incelendiğinde, 5 öğretmenin (\% 3,49) "engelleri aşma" temasi altında 5 farklı metafor geliştirdiği görülmektedir. Metaforlar incelendiğinde gerçekleştirilmesi zor olan durum ya da nesnelerle demokrasinin toplumda yerleşmesi süreci arasında bir bağlantı kurulmak istenmiştir. Örneğin ders çalışmak birçok öğrenci açısından zordur. Ancak başarıya ulaşmak için gereklidir ve gerçekleştirildiğinde ise öğrenciyi başarıya götürür. Sur metaforuna göre de surları aşıp kelenin içine girmenin zorluğu anlatılmaktadır. Özellikle de matematik metaforunun gerekçesi açıklanırken demokrasinin toplumlar açısından bir yaşam biçimi ve kültür olduğu dile getirilmiştir. Demokratik bilincin gelişmesinin özellikle de geleneksel yapılanması olan toplumlar için oldukça zor ve zahmetli bir süreç olduğu ifade edilmiştir. Genel olarak öğretmenler "engelleri aşma" teması kapsamında ortaya koydukları metaforlarla birtakım zorluklarla mücadele edilmeden güzel şeyler elde edilemeyeceğini belirtmiştir. Bu tema altında yer alan metaforlarda demokrasinin bir toplumda yerleşmesine ilişkin sürecin oldukça zor olduğu gerçeğinin vurgulandığı görülmektedir. Öğretmenlerin "ideal demokrasi anlayışı” temasına ilişkin geliştirmiş oldukları metaforlar ve gerekçelerinden örnekler Tablo 3'te verilmiştir.

Tablo 3

İdeal Demokrasi Anlayış̧ı Temasına İlişkin Metaforlar ve Gerekçeleri

\begin{tabular}{|c|c|c|c|c|}
\hline $\begin{array}{l}\text { Sira } \\
\text { No }\end{array}$ & Tema & Metafor & Metaforun gerekçesi & $\begin{array}{c}\text { Metafor } \\
\text { Sayis1 }\end{array}$ \\
\hline 19 & \multirow{8}{*}{ 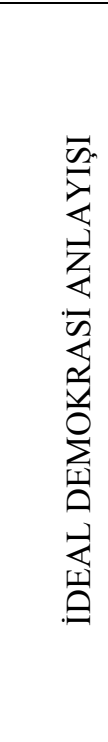 } & Şarap & $\begin{array}{l}\text { Şarabın azı kalbe ve damarlara faydalıdır. Çoğu ise zarardır. } \\
\text { Demokrasilerde de özgürlüklerin sınırlarına uygun davranılmalıdır (Erkek). }\end{array}$ & \multirow{8}{*}{5} \\
\hline 20 & & Süt & $\begin{array}{l}\text { Demokrasinin de süt gibi çok fazla faydası vardır. Ama süt bayatlarsa } \\
\text { içilemez. Zamanında tüketmek gerekir. Demokrasi de uygun zaman ve } \\
\text { platformda olmalı ve geciktirilmemelidir (Kadın). }\end{array}$ & \\
\hline 21 & & Çay & $\begin{array}{l}\text { Çay bekleyince soğur, acır, bayatlar. Fazla demokrasinin olduğu yerlerde } \\
\text { de insanlar kuralları suiistimal edebilir (Kadın). }\end{array}$ & \\
\hline 22 & & Çay & $\begin{array}{l}\text { Zamansız ocaktan alınan çay sarı su gibi olur. Ocakta çok bekletirsen acır. } \\
\text { Ölçüyü korumak gerek (Erkek). }\end{array}$ & \\
\hline 23 & & Çay & $\begin{array}{l}\text { Çayı demlenmeden içerseniz tadı olmaz. Demlikte fazla beklerse de acı bir } \\
\text { tat verir. Demokrasinin de azı ve çoğu toplumsal dengeleri bozabilir } \\
\text { (Erkek). }\end{array}$ & \\
\hline 24 & & Çay & $\begin{array}{l}\text { Çayı demledikten sonra uygun zamanda içmek gerek. Yoksa acı bir tat alır } \\
\text { ve içmesi zorlaşır. Demokrasi uygun olan zaman ve zeminde yaşanmalıdır } \\
\text { (Erkek). }\end{array}$ & \\
\hline 25 & & $\begin{array}{l}\mathrm{Su} \\
\text { damlas1 }\end{array}$ & $\begin{array}{l}\text { Su damlaları fazla olursa yağmur yağar. Yağmur iyidir ama daha fazlası } \\
\text { sele neden olur. Demokrasinin de ölçüsünü kaçırmamak lazım (Kadın). }\end{array}$ & \\
\hline 26 & & $\mathrm{Su}$ & $\begin{array}{l}\text { Su nehir yatağında aktığı kadarıyla iyidir. Ama nehir yatağından taşarsa } \\
\text { çevresine zarar verir. Demokrasilerde de özgürlükler ölçülü bir şekilde } \\
\text { çığırından çıkmadan kullanılmalıdır (Kadın). }\end{array}$ & \\
\hline
\end{tabular}

Tablo 3’teki veriler incelendiğinde, 8 öğretmenin (\% 5,59) “ideal demokrasi anlayışı” teması altında 5 farklı metafor ürettiği görülmektedir. Şarap ve süt metaforundan yola çıkılarak demokrasinin toplumsal yararları açıklanmaya çalışılmıştır. Ancak demokrasilerde de özgürlüklere konusunda ölçülü olunması gerektiği sınırsız bir özgürlüğün kişilerarası ilişkileri olumsuz yönde etkileyeceği dile getirilmiştir. "İdeal demokrasi anlayışı" teması kapsamında en çok üretilen metaforun çay olduğu görülmektedir. "Çay" metaforlarında genel olarak çayın demlendikten sonra uygun zamanda içilmesi gerekliliğine vurgu yapılmıştır. Öğretmenlere göre demokrasi de doğru zamanda ve doğru yerlerde gereklidir. Eğer gerek duyan kişiye uygun zaman ve zeminde sunulmazsa demokrasinin bir anlamı da kalmaz. Aslında öğretmenler "çay" metaforu ile ileri düzeyde ve ideal bir demokrasi talebi içinde olduklarını belirtmektedir. Toplumsal değerler korunarak, başkalarının özgürlüklerine saygı gösterilen, sınırları makul bir şekilde belirlenmiş bir demokrasi anlayışı ortaya konulmuştur. Öğretmenlerin "fedakârlık ve empati" temasıyla ilgili oluşturulmuş metaforlar ve gerekçelerinden örnekler Tablo 4 'te verilmişstir. 
Tablo 4

Fedakârlık ve Empati Temasına İlişkin Metaforlar ve Gerekçeleri

\begin{tabular}{|c|c|c|c|c|}
\hline $\begin{array}{l}\text { Sira } \\
\text { No }\end{array}$ & Tema & Metafor & Metaforun gerekçesi & $\begin{array}{c}\text { Metafor } \\
\text { Say1s1 }\end{array}$ \\
\hline 27 & \multirow{11}{*}{ 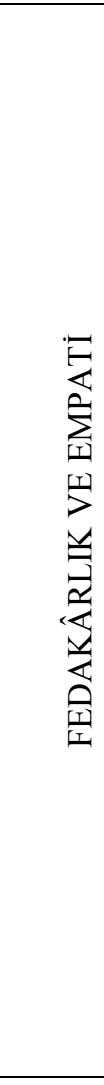 } & Anne & Çünkü doğru davranışları ilk anne öğretir bize. & \multirow{11}{*}{11} \\
\hline 29 & & Baba & $\begin{array}{l}\text { İnsan demokrasinin getirdiklerini bilirse karşısındakine sıcak ve } \\
\text { anlayışlı yaklaşır. Karşısındakinin haklarına saygılı olur. Kendini onun } \\
\text { yerine koyar (Kadın). }\end{array}$ & \\
\hline 30 & & Bebek & $\begin{array}{l}\text { Bir bebeğin bakımına ne kadar önem verirseniz bebeğiniz o denli } \\
\text { sağliklı ve mutlu olur. Demokrasinin de bir topluma yerleşmesine ne } \\
\text { kadar özen gösterirseniz o toplumda o kadar huzur olur (Kadın). }\end{array}$ & \\
\hline 31 & & $\begin{array}{l}\text { Yeni doğmuş } \\
\text { bebek }\end{array}$ & $\begin{array}{l}\text { Bebeğe sevgi ve sabır gösterilir. Demokrasinin de bir topluma } \\
\text { yerleşmesi için sabırlı olmak gerekir (Erkek). }\end{array}$ & \\
\hline 33 & & Bilge dede & $\begin{array}{l}\text { Olgunlaştıkça yaşam deneyimi artar. Farklılıklar anlayışla karşılanır. } \\
\text { Karşındakiyle empati kurabilme becerisi artar (Kadın). }\end{array}$ & \\
\hline 35 & & Ağabey & $\begin{array}{l}\text { İyi bir ağabey olmak için sevgi, adalet ve eşitlik kavramlarına sahip } \\
\text { olmak gerekir. Demokrasi de bunları gerektirir (Erkek). }\end{array}$ & \\
\hline 39 & & Öğretmen & $\begin{array}{l}\text { Çünkü adaletin, eşitliğin sembolüdür. Öğrencilerine sevgiyle yaklaşır } \\
\text { (Erkek). }\end{array}$ & \\
\hline 40 & & $\begin{array}{l}\text { Çocuğun } \\
\text { bakişı }\end{array}$ & $\begin{array}{l}\text { Çocuğun bakışında bir huzur vardır. Art niyetli değildir. Demokrasiler } \\
\text { de sevgi ortamını sağlar. Demokrasinin tam olarak sağlandığı ortamlar } \\
\text { huzur vericidir (Kadın). }\end{array}$ & \\
\hline 42 & & Çocuk & $\begin{array}{l}\text { Bir aile için en önemli kişidir. Çocuk yetiştirmek kolay değildir, } \\
\text { fedakârlık ister. Demokrasi de uzun soluklu, zor bir yolculuktur } \\
\text { (Kadın). }\end{array}$ & \\
\hline 43 & & Sevgili & $\begin{array}{l}\text { İkili ilişkilerde bile demokrasi anlayışı hüküm sürer. Farklı iki insan } \\
\text { birbirini farklılıkları yüzünden kırmazsa demokrasiyi yaşamış olurlar. } \\
\text { Farklılıklar güzellik katar hayatımıza. Farklılıklar sayesinde } \\
\text { karşımızdakiyle empati kurabiliriz (Kadın). }\end{array}$ & \\
\hline 48 & & Kardeşlik & $\begin{array}{l}\text { Zor ve engebeli bir süreçtir. Birbirinden farklı olduğun için çatışmalar } \\
\text { yaşanır kardeşler arasında. Ama gene de güzeldir kardeşlik. } \\
\text { Demokrasinin olduğu yerde insanlar arasında gizli bir kardeşlik vardır } \\
\text { (Erkek). }\end{array}$ & \\
\hline
\end{tabular}

Tablo 4'teki veriler incelendiğinde, 21 öğretmenin (\% 15,38) “fedakârlık ve empati” temas1 altında 11 farklı metafor ürettiği görülmektedir. Öğretmenlerin geliştirdikleri metaforlar incelendiğinde demokrasinin gereklerine vurgu yapıldığı görülmektedir. Anne metaforları ile başkalarına karşı doğru davranmanın önemi, insanları olduğu gibi kabul etme, farklılıklara saygı gösterme, her şeye rağmen insanları sevme gerekliliği vurgulanmıştır. Baba metaforu ile toplumda süregelen otoriter baba tavrına karşı eleştirel bir bakış ortaya konulmuştur. Öğretmelere göre toplum da geliştirdiği demokratik tavırla kişiler arası ilişkilerin daha güzel ve istenilen düzeyde olmasını sağlayabilir. Bebek/yeni doğmuş bebek metaforu ile demokrasinin ancak sabırla geliştirileceğine vurgu yapılmıştır. Bilge dede ve kardeşlik metaforları ile farklılıkları kabul etmenin güzelliği; ağabey ve öğretmen metaforu ile de adalet/eşitlik değerlerinin demokrasiyi beslediği belirtilmiştir. Çocuğun bakışı metaforu ile demokrasi için sevginin gerekliliğine; Çocuk metaforu ile demokrasinin toplum açısından vazgeçilmezliğine vurgu yapılmıştır. Öğretmenler "fedakârlık ve empati" temasında yer alan metaforlarla demokrasinin tam olarak oluşması için gereken tavır ve duruşları ortaya koymuştur. Demokrasi kendi içinde çok boyutu olan aynı zamanda bütünsel bir süreçtir. Her bir boyut sağlıklı bir toplum yapısı için oldukça önemlidir. Öğretmenler demokrasinin gelişmesi için gerekli olan durumların farkındadır. Tablo 5'te öğretmenlerin "demokrasinin topluma kazandırdıkları" temasına ilişkin geliştirmiş oldukları metaforlar ve gerekçeleri sunulmaktadır. 
Tablo 5

Demokrasinin Topluma Kazandırdıkları Temasına İlişkin Metaforlar ve Gerekçeleri

\begin{tabular}{|c|c|c|c|c|}
\hline $\begin{array}{l}\text { Sira } \\
\text { No }\end{array}$ & Tema & Metafor & Metaforun gerekçesi & $\begin{array}{l}\text { Metafor } \\
\text { Sayıs1 }\end{array}$ \\
\hline 49 & \multirow{6}{*}{ 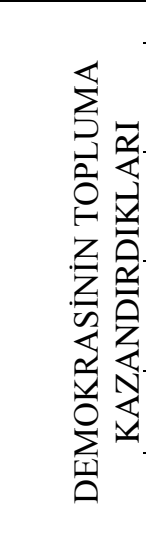 } & Çiçek & Düzenli bir bakım gerektirir. Bakmaz isen kurur, yok olur (Kadın). & \multirow{6}{*}{6} \\
\hline 50 & & Orman & $\begin{array}{l}\text { Ormanların sayısız yararı vardır. Demokratik bir anlayışın da topluma zararı } \\
\text { yoktur ve yararları sayısızdır. Ormanları korumazsanız nefes alamazsınız. } \\
\text { Demokrasiyi korumazsanız toplumsal düzeni koruyamazsınız (Erkek). }\end{array}$ & \\
\hline 51 & & Gül & $\begin{array}{l}\text { Gülün her rengi etrafa güzellik katar. İnsanlar gülleri sever. Empati de bu } \\
\text { farklı güllerin güzelliği gibidir. Demokrasi de karşılıklı empati sayesinde } \\
\text { toplumlara huzur ortamı sağlar (Erkek). }\end{array}$ & \\
\hline 53 & & Lale & $\begin{array}{l}\text { Laleler rengârenktir ancak birlikte olunca uyum içinde güzel görünür. } \\
\text { Farkl1likların olduğu toplumlarda demokrasiyi yaşatmak zor olsa bile daha } \\
\text { keyif vericidir (Kadın). }\end{array}$ & \\
\hline 54 & & $\begin{array}{l}\text { Çiçek } \\
\text { bahçesi }\end{array}$ & $\begin{array}{l}\text { Çiçeklerin ayrı ayrı güzelliklerinin birleşmesiyle bütünsel bir manzara ortaya } \\
\text { çıar (Kadın). }\end{array}$ & \\
\hline 55 & & Nar ağacı & $\begin{array}{l}\text { İlk görüşte } 1 \text { tanedir ama içinde birden fazla tane vardır. Demokrasi; } \\
\text { toplumsal yaşam, iş bölümü, emek, temel hak ve özgürlükler gibi birçok } \\
\text { kavramı içinde barındırır (Kadın). }\end{array}$ & \\
\hline
\end{tabular}

Tablo 5'teki veriler incelendiğinde, 7 öğretmenin (\% 4,89) "Demokrasinin topluma kazandırdıkları" teması altında 6 farklı metafor geliştirdiği görülmektedir. Bu metaforların bitkileri farklı yapan niteliklerden üretilmiş olması dikkat çekici bir durumdur. Bu temaya yönelik geliştirilen metaforların gerekçeleri ele alındığında, öğretmenler açısından demokrasi kavramının kendilerinde farkl1lık yaratacak bir çağrışım yaptığı söylenebilir. Çiçek metaforunda, çiçeklerin düzenli bakım istediği aksi taktirde ölebilecekleri belirtilmiştir. Bu metaforlar demokrasinin istikrarı ve sürekliliği için hassasiyet gösterilmesi gerektiğine vurgu yapılmıştır. Orman metaforunda ormanın insanlar açısından sayısız yararı olduğu belirtilmiştir. Aslında insanların yaşaması için ormanları korunması gerektiği bilinen bir gerçektir. Demokrasi de tıpkı ormanlar gibi insanları huzurlu ve düzen içinde yaşamasını sağlar. Demokrasinin olmadığı bir toplumda bütün kurumlar işlevini gerektiği gibi yapmaz elbette bu da toplumsal düzeni olumsuz yönde etkiler. Gül metaforunda, kokusu ve güzelliğiyle gülün insan yaşamını güzelleştirdiği belirtilmektedir. Öğretmenler bu metaforda demokrasinin insan yaşamını güzelleştirdiğine yaşam kalitesine arttırdığına vurgu yapmaktadır. Öğretmenlerin "Farklılıkları Kabul Etme" temasında geliştirmiş oldukları metaforlar ve gerekçelerden örnekler Tablo 6'da verilmiştir.

Tablo 6

Farklılıkları Kabul Etme Temasına İlişkin Metaforlar ve Gerekçeleri

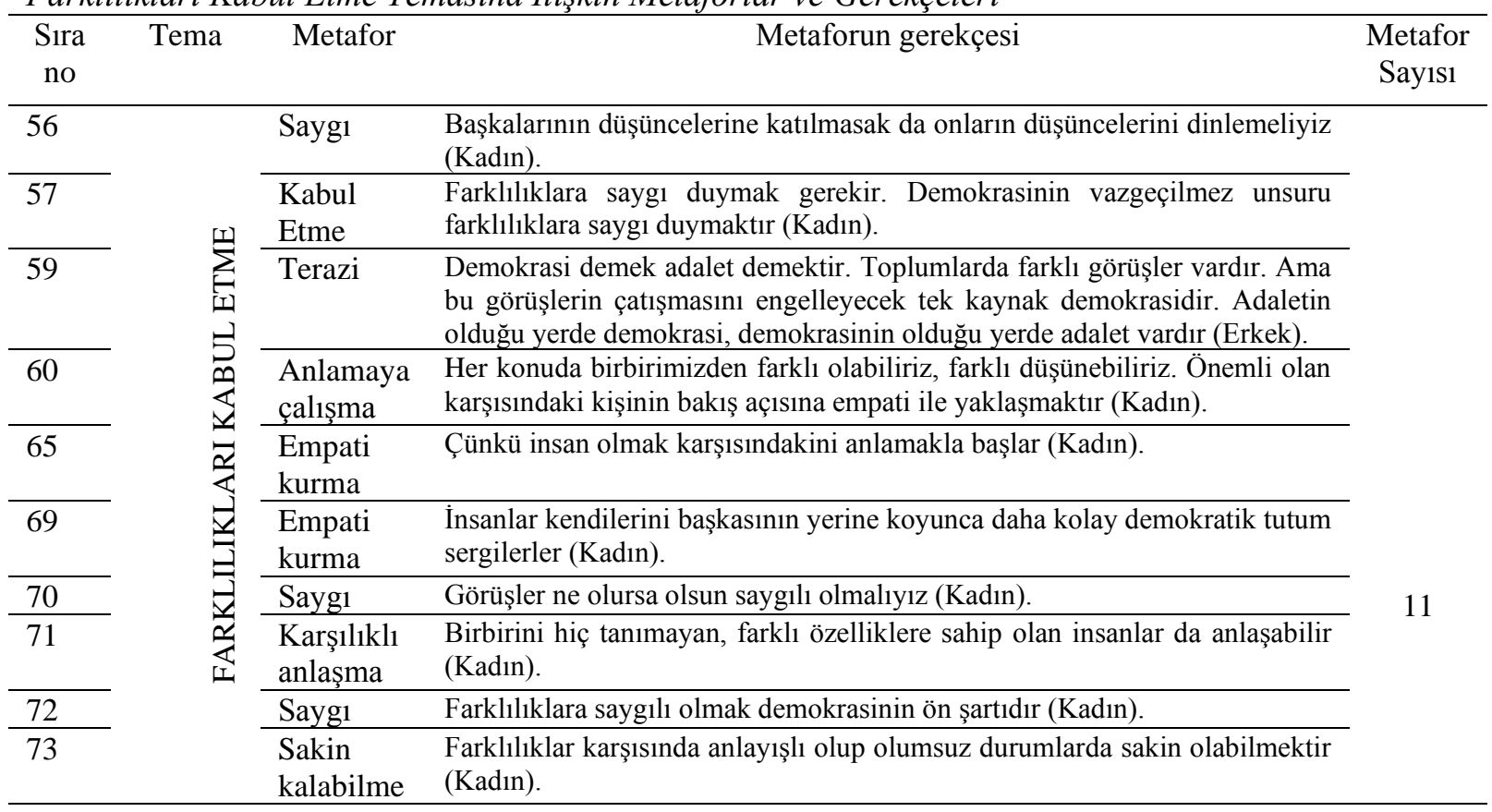




\begin{tabular}{|c|c|c|}
\hline 74 & Sayg1 & $\begin{array}{l}\text { Demokrasi başkalarının inançlarına, düşünce ve görüşlerine saygı duymaktır } \\
\text { (Erkek). }\end{array}$ \\
\hline 75 & Terbiye & $\begin{array}{l}\text { Bilgin, ahlaklı, terbiyeli kişinin demokrasi bilinci } \\
\text { Demokrasilerde tek doğru yoktur (Kadın). }\end{array}$ \\
\hline 76 & $\begin{array}{l}\text { Olumlu } \\
\text { bak1ş }\end{array}$ & $\begin{array}{l}\text { Karşısındakine olumlu bakabilen insanlar hem kendisinin hem de toplumun } \\
\text { yaşam seviyesini yükseltirler (Erkek). }\end{array}$ \\
\hline 78 & Anlayış & $\begin{array}{l}\text { Gerektiğinde alttan almak, gerektiğinde kendinden taviz vermen gerekir } \\
\text { (Erkek). }\end{array}$ \\
\hline 79 & Eşitlik & $\begin{array}{l}\text { Herkesin eşit olması karşımızdakine adaletli yaklaşmamızda önemli bir } \\
\text { unsurdur (Erkek). }\end{array}$ \\
\hline
\end{tabular}

Tablo 6'daki veriler incelendiğinde, 25 öğretmenin (\% 17,48) "farklılıkları kabul etme" temas1 altında 11 farklı metafor geliştirdiği görülmektedir. "Sayg1" metaforunda demokrasinin insanlar arasındaki ilişkileri kolaylaştırma yönüne vurgu yapılmıştır. Kendisi gibi düşünmeyeni kabul etmenin önemi, farklı düşünceleri kabul eden insanların çevresinden sayg1 gördüğü, başka inançları anlayışla karşılamak gerektiği belirgin bir şekilde vurgulanmıştır. Bunlar demokratik yaşam biçimini benimsemiș toplumlarda olması gereken değerlerdir. "Kabul etme" metaforu ile farklılıkları anlayışla karşılamak gerektiği, her insanın kendine özgü farklılıklarının olduğu ve bunun doğal karşılanmasının önemi, var olan yaşam biçimlerini değiştirmeye çalışmanın ya da kendine özgü yaşayanlara müdahale etmenin doğru olmadığı belirtilmiştir. "Empati" metaforu ile öğretmenler, başkalarını anlamaya çalışmanın kendini onun yerine koymanın, insan ilişkilerini kolaylaştırdığını belirtmiştir. Empati kurmaya çalışmak ve bunu başarmak bir başkasını bir birey olarak kabul etmek anlamına gelmektedir. "Terazi ve eşitlik" metaforu ile demokratik bir toplumda eşitlik ve adaletin olması vazgeçilmezliği; hukuk sisteminin dolayısıyla da adaletin olması gerektiği vurgulanmıştır. Demokratik toplumlarda adalet sistemi tarafsız bir şekilde işlemesinin önemi dile getirilmiştir. "Terbiye" metaforunu oluşturan ögretmen ise demokrasi bilinci gelişmiş bir insanın aynı zamanda ahlaklı ve bilge olduğunu ifade etmektedir. Bu metaforu oluşturan öğretmen demokratik anlayışa sahip bireyin erdemli ve bilge insan olduğunu vurgulamaya çalışmıştır. Öğretmenlerin ifade ettiği bu gerekçeler demokratik tutumun yaşama geçirilmesi için oldukça gereklidir. Öğretmenlerin demokratik bir ortamın oluşması için neler yapılması gerektiğine ilişkin yüksek bir farkındalığa sahip olduğu söylenebilir. Öğretmenlerin "Demokrasinin Eşitlikçi Yanı" temasında geliştirmiş oldukları metaforlar ve gerekçelerinden örnekler Tablo 7'de verilmiştir.

\section{Tablo 7}

Demokrasinin Eșitlikçi Yanı Temasına İlişkin Metaforlar ve Gerekçeleri

\begin{tabular}{|c|c|c|c|c|}
\hline $\begin{array}{l}\text { Sira } \\
\text { No }\end{array}$ & Temalar & Metafor & Metaforun gerekçesi & $\begin{array}{c}\text { Metafor } \\
\text { Say1s1 }\end{array}$ \\
\hline 80 & \multirow{9}{*}{ 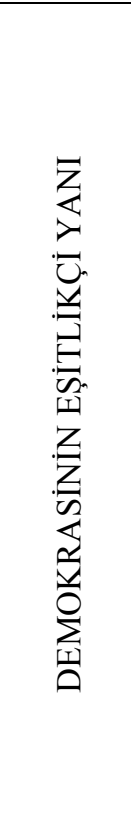 } & Bulut & $\begin{array}{l}\text { Yağmur yağar. Yağmurla doğaya huzur ve bereket gelir. } \\
\text { Demokrasi de toplumsal huzur ve bereketin kaynağıdır (Kadın). }\end{array}$ & \\
\hline 81 & & $\begin{array}{l}\text { Denizin } \\
\text { dalgası }\end{array}$ & $\begin{array}{l}\text { Dalga sakinken de hırçınken de bize aynı huzuru verir. Bazen } \\
\text { toplumlarda huzursuz ortamlar olabilir. Demokrasi ile sakinlik ve } \\
\text { huzur sağlanır (Kadın). }\end{array}$ & \\
\hline 82 & & Güneş & Bizi aydınlatır ve 1sıtır. Ayrım yapmaz (Erkek). & \\
\hline 83 & & Yağmur & $\begin{array}{l}\text { Yağmur yağarken herkesi eşit oranda 1slatır. Ama herkesin } \\
\text { yağmura karşı farklıdır. Kimi 1slanmayı sever, kimi sevmez } \\
\text { (Erkek). }\end{array}$ & \\
\hline 84 & & Toprak & $\begin{array}{l}\text { Toprak, içine iyi ya da kötü biri gömüldüğünü umursamaz ve } \\
\text { bütün varlığı sindirir. Toprağı içinde herkes eşittir. } \\
\text { Demokrasilerde de insanlar eşit muamele görür (Erkek). }\end{array}$ & \multirow{5}{*}{14} \\
\hline 86 & & Deniz & $\begin{array}{l}\text { Denizler uçsuz bucaksızdır. Denizdeki yaşamda hep bir mücadele } \\
\text { vardır. Özgürlük ve mücadele aynı anda yaşanır. Demokrasi de } \\
\text { insanların yaşam mücadelesinde yardımcı olur (Erkek). }\end{array}$ & \\
\hline 88 & & Kar tanesi & $\begin{array}{l}\text { Kar taneleri birbirine zarar vermeden yeryüzüne ulaşır. Hiçbiri } \\
\text { diğerine benzemez ama birbirine de değmez. Her kar tanesi kendi } \\
\text { farklıllı̆ı ile özgürdür (Kadın). }\end{array}$ & \\
\hline 89 & & Okyanus & $\begin{array}{l}\text { Demokrasi tıpkı okyanus gibi tüm farklılıkları içinde barındıran } \\
\text { bir sınırsızlıktır. Demokraside de tüm farklılıklar çağdaşça yaşanır } \\
\text { (Kadın). }\end{array}$ & \\
\hline 98 & & Yeryüzü & Yeryüzü çok büyüktür. Yeryüzünde her canlı mevcuttur ama bir & \\
\hline
\end{tabular}




\begin{tabular}{|c|c|c|}
\hline & & arada yaşayabilir (Kadın). \\
\hline 100 & Akarsu & $\begin{array}{l}\text { Her akışı temiz bir suyun geldiğini gösterir. Kirliliği temizler } \\
\text { (Erkek). }\end{array}$ \\
\hline 101 & Tabiat ana & Tabiat anayı nankörce kullansak bile bize yüz çevirmez (Erkek). \\
\hline 105 & Bahar & $\begin{array}{l}\text { Her bahar yeni bir uyanış yeni bir arayıştır. Huzur verir. } \\
\text { Demokrasi de uyanmak ve özgürlük aramaktır (Kadın). }\end{array}$ \\
\hline 106 & Gökkuşağ1 & $\begin{array}{l}7 \text { renk vardır. Her renk de birbiriyle barışıktır. Hepsi farklı } \\
\text { olmasına rağmen muhteşem bir uyum vardır. Demokrasi de } \\
\text { herkese tahammül edebilmektir (Erkek). }\end{array}$ \\
\hline
\end{tabular}

Tablo 7'deki veriler incelendiğinde, 25 öğretmenin $(\%$ 17,48) "demokrasinin eşitlikçi yanı" teması altında 14 ayrı metafor geliştirdiği görülmektedir. "Bulut ve bahar" metaforları ile demokrasinin toplumda sağladığı huzur dile getirilmiştir. Bu metaforlarda demokrasinin getirileri sayesinde huzurlu toplumlar oluşacağına vurgu yapılmıştır. "Güneş" metaforu oluşturan öğretmenler genel olarak demokrasinin tıpkı bir güneş gibi toplumu aydınlattığını dile getirmiştir. Güneşin insanlara eşit bir şekilde ulaştığ olması gerektiğine vurgu yapılmıştır. Diğer taraftan "güneş" metaforlarında demokratik toplumlarda sağlıklı iletişim kurabilen aydın, mutlu ve eşitlikten yana insanlar olacağı belirtilmiştir. Bu metaforda demokrasi ile insanların temel gereksinimlerinden biri olan hak ve özgürlügün önemsendiği gerçeği ön plana çıkarılmıştır. "Deniz dalgası ve toprak" metaforu ile demokrasinin toplumsal karışıklıkların olduğu dönemlerde bir tampon görevi gördüğü, yeniden huzur ortamını sağlamada etkili olduğu belirtilmiştir. "Yağmur" metaforun da herkesin farklı bir dünya görüşünün olduğu, demokrasiye ilişkin olarak da algıların farklı olacağı ifade edilmiştir. "Deniz ve okyanus" metaforlarında demokrasinin farklı anlayış ve yaşam biçimleri kucakladığı ifade edilmiştir. Demokrasinin eşitlikçi yanı dile getirilmiştir. Bu metaforlara göre -demokrasi sayesinde- insanlar dini, dili ve rengi ne olursa olsun bir arada yaşayabilir. "Kar tanesi" metaforunda insanların kendi sınırları içerisinde başkalarına zarar vermeden yaşamaları gerektiği vurgulanmıştır. Öğretmelerin "demokrasinin özgürlükçü yanı" temasına ilişkin geliştirmiş oldukları metaforlar ve nedenlerinden örnekler Tablo 8'de verilmiştir.

Tablo 8

Demokrasinin Özgürlükçü Yanı Temasına İlişkin Metaforlar ve Gerekçeleri

\begin{tabular}{|c|c|c|c|c|}
\hline $\begin{array}{l}\text { Sira } \\
\text { No }\end{array}$ & Tema & Metafor & Metaforun gerekçesi & $\begin{array}{c}\text { Metafor } \\
\text { Say1s1 }\end{array}$ \\
\hline 107 & \multirow{5}{*}{ 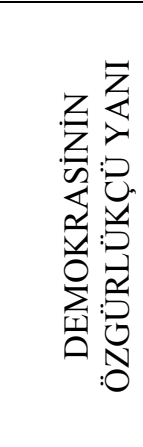 } & Evren & $\begin{array}{l}\text { Evrende binlerce y1ldı, gezegen vardır ve bunlar aralarındaki } \\
\text { farklılıklara rağmen mükemmel bir düzen oluşturuyorlar (Kadın). }\end{array}$ & \multirow{5}{*}{5} \\
\hline 110 & & Ufuk & Demokrasi de ufuk gibi sonsuzdur (Erkek). & \\
\hline 111 & & Gökyüzü & İçinde ne yaşarsa yaşasın insanlığı kucaklamaya devam eder (Kadın). & \\
\hline 114 & & Yild1z & $\begin{array}{l}\text { Demokrasinin olduğu toplumlar 1şı saçar. Demokrasi gökteki yıldız } \\
\text { gibi parlatır toplumları. İnsanların temel hak ve özgürlüklerine sayg1 } \\
\text { duyulmasını sağlar. Geniş bir yelpazede özgür bırakır bireyleri (Kadın). }\end{array}$ & \\
\hline 115 & & Dünya & $\begin{array}{l}\text { Dünya çok büyük bir yerdir ve her rrktan, milletten insanı barındırır } \\
\text { bünyesinde. Demokrasi de farklılıkları içeren bir kavramdır. Bu } \\
\text { farklılıklar başkalarının özgürlüklerine zarar vermeden kendi } \\
\text { yaşamlarını özgürce devam ettirebilir (Kadın). }\end{array}$ & \\
\hline
\end{tabular}

Tablo 8'deki veriler incelendiğinde, 9 öğretmenin (\% 6,29) "demokrasinin özgürlükçü yanı" teması altında 5 farklı metafor geliştirdiği görülmektedir. Evren metaforu ile uzaydaki farklı özellikteki nesnelerin bir araya gelerek mükemmel bir uyum yakaladığı dile getirilmiştir. Demokratik toplumlarda da farklı kültürler, inançlar ve yaşam biçimleri birbirini tamamlayan bir legonun parçaları gibi gibidir. $\mathrm{Bu}$ metaforda demokrasinin farklılıkları birleştirmedeki özelliğine vurgu yapılmıştır. "Ufuk, gökyüzü ve dünya" metaforlarını oluşturan öğretmenler demokrasinin insanları kucaklayıcı yönünü dile getirmiş̧ir. "Demokrasinin özgürlükçü yanı" temasında geliştirilen metaforların gerekçeleri genel olarak incelendiğinde, öğretmenlerin demokrasiyi gökyüzü gibi uçsuz bucaksız buldukları ve demokrasinin kendi bünyesinde farklı unsurlar taşıdığına vurgu yaptıkları görülmektedir. Sosyal Bilgiler öğretmenlerinin "Demokrasi ve toplumsal huzur" temasına ilişkin geliştirmiş oldukları metaforlar ve nedenleri Tablo 9'da verilmiştir. 
Tablo 9

Demokrasi ve Toplumsal Huzur Temasına İlişkin Metaforlar ve Gerekçeleri

\begin{tabular}{|c|c|c|c|c|}
\hline $\begin{array}{l}\text { Sira } \\
\text { No }\end{array}$ & Tema & Metafor & Metaforun gerekçesi & $\begin{array}{c}\text { Metafor } \\
\text { Say1s1 }\end{array}$ \\
\hline 116 & \multirow{10}{*}{ 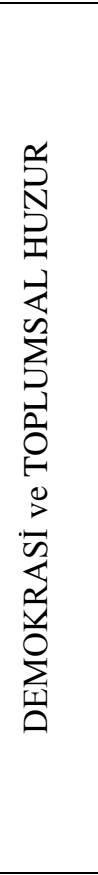 } & Pamuk şeker & Tadı ağzımızda eriyip gider ama hoş bir tat bırakır (Kadın). & \multirow{10}{*}{10} \\
\hline 117 & & Bal & $\begin{array}{l}\text { Bala çizilen iz hemen kaybolur. İz geçer ama bal tadını her zaman korur. } \\
\text { Demokrasilerde sorunlar yaşansa da yaşamı güzelleştirir (Erkek). }\end{array}$ & \\
\hline 118 & & Pasta & Çok tatlıdır ve bitmesini istemem (Erkek). & \\
\hline 119 & & Dondurma & $\begin{array}{l}\text { Sicak günlerde dondurma yemek insanı rahatlatır. Demokrasinin olduğu } \\
\text { ortamlarda da insan kendini rahat hisseder (Erkek). }\end{array}$ & \\
\hline 120 & & Supangle & $\begin{array}{l}\text { Çok severim. Yediğim zaman kendimi mutlu hissederim. Demokrasinin } \\
\text { olmadığı ortamlarda mutsuz olacağımı düşünüyorum (Erkek). }\end{array}$ & \\
\hline 121 & & Şeker & $\begin{array}{l}\text { Yiyeceklere tat verir. Yaşamı güzelleştirir. Demokrasi de yaşama tatlı } \\
\text { tadında bir anlam verir (Kadın). }\end{array}$ & \\
\hline 122 & & $\begin{array}{l}\text { Sütlacın } \\
\text { Kaymağ1 }\end{array}$ & $\begin{array}{l}\text { Sütlacın kaymağını sevmem ama altta kalan kısmı da çok severim. } \\
\text { Kısacası sütlacın hatırına kaymağını da yerim. Demokrasilerde de bazen } \\
\text { istemediğimiz, bize uygun olmadığını düşündügümüz şeyler vardır. } \\
\text { Demokrasinin getirdiklerinin yanında bu olumsuzlukları göz ardı ederiz } \\
\text { (Kadın). }\end{array}$ & \\
\hline 124 & & Bal & $\begin{array}{l}\text { Balın yapımı zordur. Ama yemesi çok güzeldir. Güzel şeylerin keyfini } \\
\text { çıarmak için zorluklarla mücadele etmek gerekir. Demokrasi anlayışını } \\
\text { topluma yerlesstirmek zordur ama demokrasinin o topluma getirdikleri } \\
\text { vazgeçilmezdir (Erkek). }\end{array}$ & \\
\hline 126 & & Gül reçeli & $\begin{array}{l}\text { Çünkü hem güzel kokar hem de tatlıdır. Yerken çok lezzetli gelir } \\
\text { (Kadın). }\end{array}$ & \\
\hline 127 & & Puding & $\begin{array}{l}\text { Puding çok lezzetlidir. Yerken büyük bir mutluluk duyarım. Demokrasi } \\
\text { ile yaşamak da insana mutluluk verir (Erkek). }\end{array}$ & \\
\hline
\end{tabular}

Tablo 9'daki veriler incelendiğinde, 12 öğretmenin $(\%$ 8,39) demokrasi kavramını tatlılarla ilişkilendirdiği görülmektedir. "Pamuk şeker, pasta, şeker ve puding" metaforları ile tatlının damakta bıraktığı lezzet ile demokrasi ilişkilendirilmiştir. Bu metaforlarda demokrasinin toplumdaki huzur ve barış ortamını sağlamadaki rolü dile getirilmiştir. Toplumumuzda var olan "ağız tadının yerinde olması" deyimi ile metaforlarda anlatılmak istenen huzurlu bir ortamın vermiş olduğu rahatlık duygusu aynı şeydir. Aslında demokratik toplum ağız tadı yerinde olan bir toplumdur. "Bal" metaforunda toplumsal huzuru sağlamanın zorluğu ve yaşanan sıkıntıların daha kolay aşılabileceği, toplumsal yaraların iz bırakmadan sarılabileceği vurgulanmaya çalışılmıştır. "Sütlacın Kaymağı" metaforunda demokrasilerde beğenilmeyen durumlara da katlanılabileceği dile getirilmiştir. İstenmeyen durum ya da olaylara karşısında tahammül etme duruşunun gerekliliği vurgulanmıştır. Öğretmenlerin "Demokrasinin Gelişim Süreci" temasında geliştirmiş oldukları metaforlar ve gerekçelerinden örnekler Tablo 10’da verilmiştir.

Tablo 10

Demokrasinin Gelişim Süreci Temasına İlişkin Metaforlar ve Gerekçeleri

\begin{tabular}{|c|c|c|c|c|}
\hline $\begin{array}{l}\text { Sira } \\
\text { No }\end{array}$ & Tema & Metafor & Metaforun gerekçesi & $\begin{array}{l}\text { Metafor } \\
\text { Sayisı }\end{array}$ \\
\hline 128 & \multirow{6}{*}{ 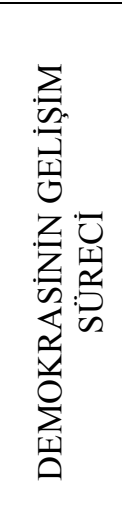 } & $\begin{array}{l}\text { Çınar ağacının } \\
\text { büyümesi }\end{array}$ & $\begin{array}{l}\text { Demokrasi büyük bir çınardır. Büyümesi için uzun yıllar beklenir } \\
\text { (Kadın). }\end{array}$ & \multirow{6}{*}{9} \\
\hline 129 & & Meyveli ağaç & $\begin{array}{l}\text { Meyveli ağaçların toplumu beslediği gibi demokrasi de toplumu besler. } \\
\text { Ama meyveli ağaç yetiştirmek de kolay değildir. Zaman ister (Kadın). }\end{array}$ & \\
\hline 130 & & $\begin{array}{l}\text { Çiçeğin } \\
\text { açması }\end{array}$ & $\begin{array}{l}\text { Çiçekler yavaş yavaş açar. Beklemek gerekir. Ama bu bekleyişin } \\
\text { sonunda huzur vericidir (Kadın). }\end{array}$ & \\
\hline 131 & & $\begin{array}{l}\text { Çiçeğin } \\
\text { büyümesi }\end{array}$ & $\begin{array}{l}\text { Bir çiçeğin büyümesini sabırla beklemek gerek. Demokrasi anlayışı de } \\
\text { bir topluma hemen yerleşmez (Kadın). }\end{array}$ & \\
\hline 132 & & $\begin{array}{l}\text { Bebeğin } \\
\text { büyümesi }\end{array}$ & $\begin{array}{l}\text { Bebeğin büyümesi için sabır ve itina gereklidir. Demokrasiyi büyütmek } \\
\text { ve topluma kazandırmak da böyle bir şeydir (Kadın). }\end{array}$ & \\
\hline 134 & & Tohum & $\begin{array}{l}\text { Tohumdan fidan, fidandan ağaç olur. Demokrasi bir topluma oturuncaya } \\
\text { kadar demokrasiyi sağlayacak eşitlik, adalet gibi etmenlerin önce o } \\
\text { topluma yerleşmesi gerek. (Kadın). }\end{array}$ & \\
\hline
\end{tabular}




\begin{tabular}{lll}
\hline 135 & Larva & $\begin{array}{l}\text { Çünkü larva zamanla kurbağaya dönüşür ve farklı bir hayvan gerçek } \\
\text { anlamda demokratik bir toplumun oluşması da zaman ister (Kadın). }\end{array}$ \\
& $\begin{array}{l}\text { Çocuğun } \\
\text { büyümesi }\end{array}$ & $\begin{array}{l}\text { Çocuk büyüdükçe gelişir. Demokrasinin uzun yıllardır yaşandığı } \\
\text { toplumlar değerlidir (Kadın). }\end{array}$ \\
\hline
\end{tabular}

"Demokrasinin gelişim süreci" temasında 10 öğretmenin $(\% \quad 6,99) 9$ metafor geliştirdiği görülmektedir. "Çınar ağacının büyümesi" metaforu ile demokrasinin toplum açısından önemli ve yüce bir değer olduğu belirtilmeye çalışılmıştır. Çınar ağacının büyüklüğü, heybeti ve büyümesinin zaman alması demokrasi ile ilişkilendirilmiştir. "Meyveli ağaç" metaforunda bu ağaçların insanların beslenmesi için önemli olduğundan yola çıkılarak demokrasinin de toplumu ayakta tuttuğuna vurgu yapılmıştır. Meyve olmadan insanların vücudunun gereksinim duyduğu vitamini karşılaması pek mümkün değildir. Bireylerin demokratik gereksinimleri karşılanmadıkça uygar bir toplum olmanın gerekleri yerine getirilemez. "Çiçeğin açmas1, çiçeğin büyümesi, bebeğin büyümesi, bebeğin gelişime ve tohum" metaforlarında genel olarak sabırlı olmanın gerekliliği belirtilmiştir. Öğretmenlerin "Sıra dışı benzetmeler" temasına ilişkin geliştirmiş oldukları metaforlar ve nedenlerinden örnekler Tablo 11 'de verilmiştir.

Tablo 11

Sıra Dışı Benzetmeler Temasına İlişkin Metaforlar ve Gerekçeleri

\begin{tabular}{|c|c|c|c|c|}
\hline $\begin{array}{l}\text { Sira } \\
\text { No }\end{array}$ & Tema & Metafor & Metaforun gerekçesi & $\begin{array}{c}\text { Metafor } \\
\text { Sayısı }\end{array}$ \\
\hline 138 & \multirow{6}{*}{ 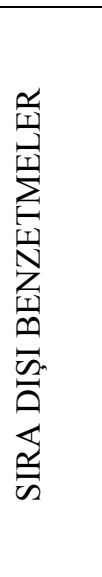 } & Rüya & $\begin{array}{l}\text { Rüya görmek insanı mutlu eder. Demokrasinin olduğu toplumlarda } \\
\text { insanlar mutludur (Kadın). }\end{array}$ & \multirow{6}{*}{6} \\
\hline 139 & & $\begin{array}{l}\text { Farklı bir } \\
\text { gezegende } \\
\text { yaşamak }\end{array}$ & $\begin{array}{l}\text { Çünkü o gezegende farklı şeylerle karşılaşırsın. Demokrasi farklılıkları } \\
\text { bir arada tutar (Kadın). }\end{array}$ & \\
\hline 140 & & Periler & $\begin{array}{l}\text { Periler yoktur. Hayal gücümüzün bir oyunudur bize. Gerçek anlamda } \\
\text { demokrasiyi yaşamıyoruz (Kadın). }\end{array}$ & \\
\hline 141 & & Kâbus & $\begin{array}{l}\text { Kâbuslar bazen korkutur. Fazla demokrasi de beni korkutur. Çünkü } \\
\text { demokrasi kavramının içeriği yanlış anlaşıldığında topluma zarar } \\
\text { gelebilir (Erkek). }\end{array}$ & \\
\hline 142 & & Uçmak & $\begin{array}{l}\text { Uçmak özgürlüğü anımsatıyor bana. Temel haklarına, özgürlüklerine } \\
\text { sayg1 gördükçe sevinirsin (Kadın). }\end{array}$ & \\
\hline 143 & & $\begin{array}{l}\text { Köpek } \\
\text { baliğıyla } \\
\text { yüzmek }\end{array}$ & $\begin{array}{l}\text { Hem ürkütücü hem de zevkli olsa gerek. Demokrasinin ayarını iyi bilmek } \\
\text { gerekli (Kadın). }\end{array}$ & \\
\hline
\end{tabular}

Tablo 11'deki veriler incelendiğinde, 6 öğretmenin (\% 4,19) "sıra dışı benzetmeler" teması altında 6 farklı metafor geliştirdiği görülmektedir. "Rüya" metaforu ile rüyaların insanı mutlu ettiği belirtilmiştir. İnsanlar olmasını istediği güzel durumları rüyalarında görür. Demokrasi de insanlara bekledikleri, yaşamak istedikleri bir dünya sunabilir. Elbette ki böyle bir ortam insanları mutlu eder. "Rüya" metaforunu ortaya koyan öğretmen gerçek anlamda demokratik bir toplum içerisinde yaşayabilme özlemini dile getirmiş olabilir. "Farklı bir gezegende yaşama" metaforu ile değişik durumlarla karşılaşmanın insanda yarattığ şaşkınlık ve heyecan dile getirilmiş̧ir. İnsanlar sıra dışı olay, yaşam biçimi ya da durum ile karşılaşınca farklı duygu hallerine bürünebilirler. Birçok insan bunu yaşamın renkli yönü şeklinde algılayabilir. Demokratik toplumlarda farklı giyinen, düşünen, inanan insanların bir arada yaşaması ve bunlarla karşılaş̧mak kişide heyecan duygusu yaratabilir. "Periler" metaforu ile toplumsal anlamda demokrasinin tam anlamıyla yaşanamadığı belirtilmiştir. "Kâbus" metaforu ile demokratik toplumlarda zararlı, istenmeyen durumlarla bir arada yaşamanın zorluğu dile getirilmiş olabilir. Kişisel değer ve tutumlara uymayan başka yaşantılar rahatsızlığa neden olabilir. $\mathrm{Bu}$ metaforu üreten öğretmen özgürlüklerin yaşanmasını korkunç bir durum olarak algılamaktadır. "Uçmak" metaforu ile temel hak ve özgürlüklere saygı duyulan bir insanın kendini iyi hissedeceğine vurgu yapılmıştır. Kabul edilmek, benimsenmek, ötekileştirilmemek her birey, grup ya da kitle için olması gerekendir. Öğretmenlerin "sıra dışı benzetmeler" temasında yer alan metaforları incelendiğinde daha yaratıcı ve sıra dışı düşüncelerin ortaya çıktığı görülmektedir. Üretilen metaforların gerekçelerine bakıldığında demokrasinin kendilerine ait farklı çağrışımlar yaptığı görülmektedir. 


\section{Sonuç, Tartışma ve Öneriler}

Araştırmaya katılan 13 öğretmenin (\% 9,09) "yaşamın olmazsa olmazı" teması ile ilgili olarak toplam 10 farklı metafor geliştirdiği tespit edilmiştir. Metaforların geliştirilme nedenlerinde öğretmenlerin demokrasinin temel bir gereksinim olduğuna, demokrasinin sosyal ve siyasal yaşamın gerekliliği için vazgeçilmez bir unsur olduğuna vurgu yaptıkları görülmektedir. Öğretmenlerin geliştirdikleri ekmek, su, güneş ve kalorifer metaforlarına bakıldığında demokrasinin bireyin hayatını sürdürebilmesi için en temel ve gerekli ihtiyaçlara benzetildiği görülmektedir. Bu veriler 1şığında öğretmenler toplumsal düzen için demokrasinin çok önemli bir unsur olduğunun farkında olduğu söylenebilir. Yüce ve Demir (2011) çalışmasında Polis Meslek Yüksek Okulu bünyesinde öğrenim gören polis adayı ikinci sınıf öğrencileri ile yaptığı görüşmelerde 9 polis adayı öğrenci demokrasiyi ürettikleri su, yemek, hava ve mobilya metaforlarına benzetmişlerdir. Bu metaforların gerekçelerine bakıldığında polis adaylarının demokrasiyi gereksinim olarak algıladıkları görülmektedir.

"Engelleri aşma" teması kapsamındaki metaforlar ve gerekçelerine göre demokrasiye ulaşmak zorluklarla mücadele gerektirmektedir. Araştırmaya katılan öğretmenlerin 5'i $(\% 3,49)$ demokratik bir toplum oluşturmanın oldukça zor olduğuna inanmaktadır. Metaforlarda gerçek demokrasinin yaşanabilmesi için birtakım zorluklarla karşılaşılabileceği ve demokrasinin toplum tarafindan benimsenmesinin oldukça zor olduğu dile getirilmiştir.

Araştırma sonuçlarına göre 8 öğretmen (\% 5,59) “ideal demokrasi anlayışı" temasına ilişkin5 farklı metafor oluşturarak demokrasiyi uygun zaman ve zeminde; ölçülü bir şekilde yaşamanın gerekliliğine vurgu yapmıştır. Katılımcılara göre demokrasilerde denge unsuru ön planda tutularak toplumun huzuru sağlanmalıdır. Sınırsız bir özgürlük anlayışı karmaşaya neden olabilir. Ancak Türkiye gibi gelişmekte olan ülkelerin toplum yapısına uygun bir demokratik ortam oluşturması için zamana gereksinim duyduğu gerçeği gözden uzak tutulmamalıdır.

"Fedakârlık ve empati" temasında 21 öğretmenin $(\%$ 14,68) 11 farklı metafor geliştirdiği görülmektedir. $\mathrm{Bu}$ öğretmenler, insan ilişkilerinin temeli olan sevgi, anlayış ve fedakârlık gereksinimini demokrasi ile ilişkilendirilmiştir. Sevgi ve anlayışlı olmanın toplumun tamamı için en önemli gereksinimlerden biri olduğu söylenebilir. Sevginin olmadığı bir toplumda anlayış, huzur ve barıştan söz edilemez. Öğretmenler demokrasinin toplumsal düzen için çok önemli bir gereksinim olduğunun farkındadır. Bu tema altında yer alan metaforlarda demokrasinin önemi, zorluğu ve gerekliliği vurgulanmaktadır.

"Demokrasinin topluma kazandırdıkları" temasında 7 öğretmenin $(\% 4,89) 6$ farklı metafor geliştirdiği görülmektedir. Üretilen metaforların gerekçelerine bakıldığında farklılıkların bir araya gelmesiyle oluşan mozaiğin topluma kattığı önemin vurgulandığı görülmektedir. Türkiye jeopolitik konumu nedeniyle farklı kültürlerin bir arada yaşadığ şekilde bu coğrafyada bir arada yaşaması için demokrasinin önemli unsurlarından olan hoşgörü ve buna bağlı olarak da yargılamadan kabullenmenin gerçekleşmesi gerekir. Öğretmenlerin ülkenin bu etnik yapısından kaynaklanan ilişkilerle ilgili belirgin bir algıya sahip olduğu söylenebilir. Empatinin olmadığı bir toplumda düzen, huzur ve barıştan söz edilemez. Öğretmenler empatinin toplumsal düzen için çok önemli olduğunun farkındadır.

"Farklı1ıkları kabul etme" temasındaki metaforların üretilme nedenlerine bakıldığında öğretmenlerin demokratik bir toplum olunması için sayg1 ve empatiye vurgu yaptığı görülmektedir. Araştırmaya katılan 25 öğretmene (\% 17,48) göre demokrasinin gelişmesi ve yerleşmesi için insanlar birbirlerinin farklılıklarına saygı göstermeli ve anlamaya çalışmalıdır. Bu metaforlarda (saygı, kabul etme, empati kurma, eşitlik vb.) çoğunlukla birbirinden farklı olmanın çatışamaya yol açmaması gerektiğine, karşılıklı empati kurmanın önemine ve birbirine anlayışla yaklaşmanın demokratik bir tutum olduğuna vurgu yapılmaktadır. "Farklılıkları kabul etme" temasında öğretmenler, demokratik toplumlarda farklı düşüncelere de hoşgörü ile bakabilmek, farklılıkları bir zenginlik olarak görebilmek ve barış içinde bir arada yaşamayı başarabilmek gerçeğine dikkat çekmiştir. Öğretmenlerin ürettiği bu metaforlarda, kendisi gibi düşünmese de karşı tarafın varlı̆̆ına empatik bir yaklaşım gösterilmesi gerektiği; saygı ve kabullenmenin demokratik davranış ve anlayışın gelişmesine ön ayak olacağı 
vurgulanmıştır. Güder ve Yıldııı'ın (2014) Okulöncesi öğretmeni adaylarının demokrasi ilişkin geliştirdikleri metaforlarla ilgili çalışmasına bakıldığında; farklı düşüncelerin bir arada olması ile demokrasi kategorisi altında 15 farklı metaforun üretildiği görülmektedir. Metaforların üretilme gerekçeleri incelendiğinde öğretmen adaylarının demokrasinin farklı görüşleri içermesi gerektiğini ve bu görüşlere saygı duyulmasının demokrasinin en önemli unsuru olduğunu vurgulamışlardır (Dündar, 2012). 8. Sinıfta okuyan 140 öğrenci ile yaptığı çalışmada, 19 öğrenci ürettiği 7 farklı metaforla demokrasinin birbirinden farklı düşünenlerin, $1 \mathrm{rk}$, mezhep veya cinsiyetleri ne olursa olsun birbirine karşı olan tahammülü arttırdığına değinmişlerdir.

"Demokrasinin eşitlikçi yanı" temasında 25 öğretmen (\% 17,48), 14 farklı metafor ortaya koymuştur. Bu metaforlarda öğretmenlerin demokrasi kavramını engin bir deniz gibi uçsuz bucaksız buldukları görülmektedir. Çoğunlukla bu metaforlarda demokrasilerde toplumsal mutluluk ve huzurun yaşanacağı dile getirilmiş̧ir. Diğer taraftan "Demokrasinin eşitlikçi yanı" temasında dikkat çeken bir başka nokta ise bireysel farklılıkların çatışmaya neden olmayacağı, aksine demokrasinin barışçı1, çatışmaları çözebilen, farklılıklara saygı gösteren, karşısındakini kabul eden ve insan hakları ilkelerinin de bulunduğu bir ortam getireceği ifadelerinin ortaya konulmasıdır. Öğretmenler oluşturdukları metaforların gerekçelerinde demokrasinin temel bileşenlerinin, farklılıkları hoşgörüyle karşılama ve kabullenme olduğunu ortaya koymuştur. Bu veriler işığında araştırmaya katılan 25 öğretmen $(\%$ 17,48) için demokrasinin hoşgörü, farklılığı kabul etme kabullenme, uzlaşmacı bir tavır içinde olma, karşılıklı iletişim kurmayı isteme, aydınlanmayı sağlama yönüne ilişkin olarak belirgin bir farkındalığa sahip olduklarını söylemek mümkündür.

"Demokrasinin özgürlükçü yanı" teması altında 9 öğretmenin $(\% \quad 6,29), 5$ farklı metafor geliştirdiği görülmektedir. Öğretmenlerin demokrasiyi uzlaşma, farklılıklara karşı hoşgörü, insana saygı, bireylerin başkalarına zarar vermeden özgürce yaşaması vb. değerlerini içeren bir kavram olarak görmesi demokrasi bilincinin geliştirilmesi konusunda bilinçli öğrenciler yetiştirilmesi adına olumlu adımlar atacakları görüşüne ulaştırabilir. Öğretmenler insanların bir arada yaşaması için sevgi, saygı, hoşgörü ve özgürlük gibi değerlerin önemine vurgu yapmıştır.

"Demokrasi ve toplumsal huzur" teması altında 12 öğretmenin $(\% 8,39)$ demokrasi kavramını tatlılarla ilişkilendirdiği görülmektedir. Demokrasi ve toplumsal huzur" temasında yer alan metaforların isimlerinin farklı tatlı türlerine ait olduğu görülse de gerekçeler genel olarak benzerdir: "Farklı nitelikteki yiyecekler bir araya geldiğinde güzel ve hoş bir manzara oluşturur. Toplumların kendi içindeki farklılıkları da bütünsel bir güzellik oluşturmaktadır." Üretilen bazı metaforlarda genel olarak tatlıya huzur, birbirini anlamanın ve kabul etmenin güzelliği anlamı yüklenmiştir. Aslında öğretmenler bu metaforlarda demokrasinin bir topluma huzur getireceğini ve demokrasinin var olduğu ortamlarda insanların kendilerini rahat hissedeceklerine vurgu yapmaktadır. Aslında bu metaforlarda insan haklarına saygı duymanın gereği olan temel davranışlara vurgu yapılmıştır.

"Demokrasinin gelişim süreci" temasında 10 öğretmen $(\%$ 6,90) 9 ayrı metafor ortaya koyarak demokrasi kültürünün bir topluma yerleşmesi sürecinin uzunluğu ve güçlükleri ile bir canlının gelişim aşamalarını ilişkilendirmiştir. Demokratik hayatın gerektirdiği olan bilgi, tutum davranışlarıyla donatılmış bireylerin yetişmesi ve bir toplumda demokrasinin yaşam biçimi haline gelmesi sürecinin zorluklarına değinen öğretmenler ürettikleri metaforlarla bu sürecin kendiliğinden gerçekleşmediğini, zor ve zahmetli bir süreç olduğunu önemle vurgulamışlardır. Araştırmaya katılan öğretmenlerin de belirttiği gibi hak ve özgürlüklerin gerektiği gibi yaşandığı; bireylerin birbirine güvendiği; bireysel ve toplumsal kararların uygun bir şekilde alınabildiği; yaratıcı düşüncelerin yadırganmadığı bir toplum olmak sanıldığı kadar kolay olmayabilir. Böylesine demokratik bir toplumsal anlayışa ulaşmak büyük ölçüde eğitimle mümkündür. Özellikle geleneklerine körü körüne bağli; taassuplar içerisinde yaşayan; çağın gereklerine ayak uydurmakta zorlanan toplumların demokrasiyi gerçek anlamda yaşayacak seviyeye gelmesi oldukça zordur ve zaman alıcıdır.

"Sıra dışı benzetmeler" teması altında 6 öğretmenin $(\%$ 4,19), 6 farklı metafor geliştirdiği görülmektedir. Sıra dışı benzetmeler teması altında geliştirilen metaforlara öğretmenlerin birbirine karşı anlayışı, hoşgörülü ve kişisel haklara saygılı olması gerektiği vurgulanmaktadır. Demokrasiyi benimsemiş bir bireyin sahip olması gereken en önemli özellikler farklı düşüncelere ve temel hak ile 
özgürlüklere saygılı olma, empati becerisine sahip olma ve karşı fikirlere açık olmasıdır. Öğretmenin demokrasinin içerdiği unsurları benimsemiş kişilik özelliğine sahip olması; sınıfta demokratik bir sınıf iklimi oluşturması ve öğrencilerinden gelebilecek farklı yorumlara herhangi bir yanlış anlaşılmaya sebebiyet vermeden demokrasinin sınıflarda öğretilmesini sağlamak adına önemlidir.

İlköğretimde çalışan Sosyal Bilgiler öğretmenlerinin demokrasiye ilişkin bakış açılarını metaforlar aracılığıyla belirlemeyi amaçlayan bu araştırmada elde edilen verilerin içerik analizleri sonucunda toplam 95 metaforun $(\mathrm{f}=66,43) 11$ farklı temada toplandığ görülmüştür. Söz konusu temalar "yaşamın olmazsa olmazı, engelleri aşma, ideal demokrasi anlayışı, farklılık ve empati, demokrasinin topluma kazandırdıkları, farklılıkları kabul etme, demokrasinin eşitlikçi yanı, demokrasinin özgürlükçü yanı, demokrasi ve toplumsal huzur, demokrasinin gelişim süreci ve sıra dış1 benzetmeler" ş̧eklindedir. Araştırma bulgularına göre sosyal bilgiler öğretmenleri tarafindan oluşturulan en fazla metaforun "demokrasinin eşitlikçi yanı (\% 14)" ve "farklılıkları kabul etme (\% 11,57) temalarında yer alırken en az metafor geliştirilen temaların ise "demokrasinin özgürlükçü yanı ve engelleri aşma $(\% 5,26)$ " temaları olduğu görülmektedir. Demokrasinin eşitlikçi yanı ve farklılıkları kabul etme temaları adı altında üretilen metaforların gerekçelerinde çeşitlilik, anlayış, saygı, denge, adalet, sabır, farklılık, gereklilik, önem ve empati kavramlarını içeren ifadelerin yer aldığ 1 dikkat çekmektedir. Bu ifadelerden öğretmenlerin demokrasi kavramının toplumun refah ve huzuru için vazgeçilmez bir unsur olarak algıladığ gerekçelerinde vurgulanan kavramların yaşama geçirilmesi için gerekli olduğu görülmüştür. Sinatra, Beck ve McKeown (1992) çalışmalarında sekizinci sınıf 26 öğrenci ile hazırladıkları görüşme formunda bulunan sorular çerçevesinde görüşmeler yapmıştır. Görüşmelerin sonunda araştırmacılar öğrencilerin demokrasi algılarının oldukça zayıf kaldığını belirtmiştir. Öğrencilerin demokrasinin içerdiği çeşitlilik, saygı, denge ve anlayış gibi kavramlara değinmediklerini belirtmiştir. Ayrıca öğrencilerin kendi ülkelerinde yaşanan demokrasiyi olumsuz etkileyebilecek olaylar hakkında bilgi sahibi olmadıklarına da dikkat çekmiştir.

Üretilen metaforlara bakıldığında 7 (\% 4,89) öğretmenin (14, Kadın; 15, Kadın; 16, Kadın; 17, Kadın; 18, Kadın; 18, Kadın; 141, Erkek) demokrasi kavramına yönelik olumsuz metafor (Ders çalışmak, Öğrenme, Hakem, Sur, Matematik, Kâbus) ürettiği buna karşılık olarak da 136 öğretmenin $(\% 95,10)$ olumlu metafor ürettiği tespit edilmiştir. Olumsuz üretilen metaforların gerekçelerine bakıldığında hepsinde bir zorluktan bahsedildiği görülmüştür. Kadın öğretmenlerin daha fazla olumsuz metafor üretmesi ve üretilen metaforların gerekçelerinde demokrasinin topluma yerleşmesinin zor olduğuna vurgu yapılması kadınların haklarını yeterli derecede savunamaması, erkeklerle aynı haklara sahip olamaması, kadınların erkeklere oranla kendilerini rahatça ifade edememesi gibi nedenlerin olabileceği düşünülmektedir. Bu sonuçlara göre, Kadınlar demokrasinin bir gereklilik olduğunu düşünmesine rağmen erkek egemen bir toplum düzeninde yaşadıkları için demokrasinin gereklerine uygun davranış geliştirmenin güçlüklerini ortaya koyduğu düşünülebilir. Kuş ve Çetin (2014) çalışmalarında 6., 7. ve 8. sınıfta öğrenim gören toplam 1667 öğrenci ile tarama modeli çerçevesinde "Demokrasi Algısı Ölçeğì" kullanarak gerçekleştirdikleri çalışmasında kız öğrencilerin demokrasiyi erkek öğrencilerden daha olumlu ve doğru bir biçimde algıladıkları tespit etmiştir. Diğer bir deyişle demokrasi gereksinimi kadınlarda daha güçlü bir gereklilik olarak algılanmakatadır. Ayrıca demokrasi algısı ölçeğindeki maddeler tek tek incelendiğinde de kız öğrencilere ait ortalamanın erkek öğrencilerden daha yüksek olduğu görülmektedir. Kuş (2012) çalışmasında yurt dışından Türkçeye uyarlanan Demokrasi Algısı Ölçeğini Dünya'da 28 ülkeye, Türkiye'de ise 26 ilden tabakalı örneklem modeli ile seçilen 6., 7. ve 8. sinıflarda öğrenim gören toplam 1667 öğrenciye uygulamıştır. Türkiye'de demokrasi algısı ölçeğinden elde edilen ortalamaları ile bu çalışmanın yapıldığı diğer 28 ülkenin ortalamaları arasında farklılık bulunmuştur. Genel olarak olumlu maddelerdeki ortalamaların Türkiye'de öğrenim gören öğrencilerde düşük olduğu, olumsuz maddelerde ise Türkiye'deki öğrencilerin demokrasi algısının diğer 28 ülkedeki öğrencilere göre daha yüksek olduğu sonucuna ulaşılmıştır. İpek (2011) Sosyal Bilgiler ders kitaplarının içeriği ile ilgili yaptığ 1 çalışmasında, Demokrasi kavramı ve eğitiminin ders kitaplarında ağrılılıklı olarak bilgi düzeyinde kaldığını ve bu nedenle demokrasinin teorik düzeyde anlaşılmasına neden olduğu sonucuna ulaşmıştır. Ayrıca kitaplarda yer alan bilgilerin demokratik hakların kullanılmasını teşvik etmekten ziyade, bu hakların istismar edildiği bu hakların istismar edildiği örneklerin ders kitaplarında yer 
alması, öğrencilerde bu haklara yönelik olumsuz izlenim yarattığı belirtilmiştir. Öğrencilerin gelişim dönemleri dikkate alındığında kitaplarda verilecek örneklerin olumsuz ifadeler içermesinin uygun olmadığına vurgu yapılmıştır. Kuş, Sönmez ve Karatekin (2011) "Okulda Yaşam Biçimi Olarak Demokrasi Eğitimi” adlı çalışmalarında hem dünyada hem de Türkiye'de bugüne kadar demokrasi eğitiminin daha çok bilgi boyutu üzerinde durulduğunu tutum, beceri ve uygulama boyutunun ihmal edildiğini vurgulamaktadır.

Demokrasinin gelişmesi için Sivil Toplum Kuruluşlarının (STK) yeri ve önemi yadsınamaz. Araştırmanın geneline bakıldığında öğretmenlerin Sivil Toplum Kuruluşlarıyla ilgili herhangi bir metafor üretmediği görülmektedir. Harber (2002), bir toplumda sivil toplum örgütlerinin gelişmesinin demokrasi anlayışının gelişebilmesine çok önemli katkı yaptığını belirtmektedir. Bu durum toplumsal örgütlenme alışkanlığ 1 ve bilincinin tam olarak gelişmediğinin bir göstergesi olabilir. Kuş (2012) Türkiye geneli 26 ilde yapmış olduğu çalışmasında öğrencilerin, sivil toplum kavramına uzak olduğu, bu konuda bilgi sahibi olmadıkları sonucuna ulaşmışırı. Demokratik hakların kullanımı için en önemli kurumlardan sendikalaşmanın ve sendikal hakların kullanımına yönelik yetersizilik de öğretmen ve öğrencilerin demokrasiye olan inancını azaltmasına neden olabilmektedir.

Demokrasi kavramı içerisinde bulunan eşitlik, çocuk hakları, siyasi partiler, özgürlük adalet, karar verme, katılım ve seçim boyutlarını ele almadıkları görülmektedir. Bununla birlikte öğretmenlerin demokrasi ile ilgili geliştirdiği metaforlara (Güneş, Uçmak, Nar ağacı) bakıldığında demokrasinin en önemli ayırt edici unsurlardan olan temel hak ve özgürlükler konusuna sadece 3 öğretmenin (\% 2,09) özel olarak vurgu yaptığı (55 Kadın, 87 Kadın ve 142 Kadın) görülmektedir. Üretilen bu 3 metafordan "Uçmak" metaforunun gerekçesine bakıldığında 142, Kadın Öğretmen; uçmanın özgürlüğü anımsattığını, insanların temel haklarına ve özgürlüklerine sayg1 gördükçe sevineceğine değinmiştir. 87, Kadın Öğretmen; "Güneş" metaforuyla demokrasinin görevinin toplumdaki temel hak ve özgürlükleri düzene sokmak olduğunu belirtmiştir. "Nar ağacı" metaforunu kullanan öğretmen (55, Kadın) Demokrasinin toplumdaki temel hak ve özgürlüklerini düzene sokmak görevinden bahsetmiştir. Erkek öğretmenlerin temel hak ve özgürlüklere vurgu yapmaması ve buna karşılık sadece 3 kadın öğretmenin bu konuya vurgu yapması öğretmenlerin demokrasinin ayırt edici özelliği olan temel hak ve özgürlüklere yeterli önemi vermediğini ortaya koymaktadır. Araştırmada, kadın öğretmenlerin temel hak ve özgürlükler ile ilgili metaforlar geliştirmesi bu alanlarda daha hassas, düşünceli ve mücadeleci olduğunu göstermektedir. Güder ve Yıldırım'ın (2014) okulöncesi öğretmeni adaylarıyla yaptığı çalışmada öğretmen adaylarının demokrasiyle ilgili geliştirdikleri metaforları tespit etmeye çalışmıştır. Bu araştırmada da öğretmen adaylarının temel insan haklarına ilişkin metaforlara yer vermediği tespit edilmiştir. Bireylerin aldıkları eğitim boyunca demokrasinin sadece yönetim biçimi boyutuyla karşılaştıklarını, demokrasinin insan hakları boyutunda yer alan temel hak ve özgürlüklerin gerektiği gibi gündeme gelmediğini söylemek mümkündür. Bu durumun öğretmen adaylarının konuya ilişkin metafor üretememesi üzerinde etkili olduğu düşünülebilir.

Öğretmen eğitimi programlarında demokrasi eğitimine ilişkin teorik bilgilerin yüklemesini yapmak yerine bu bilgileri kullanılmasını sağlayacak pratik uygulamaların da yer alması son derece önemlidir. Öğretmenlere demokrasi eğitimine yönelik programlar geliştirilip deneysel çalışmalar yapılarak etkililiği sınanabilir. Öğretmenlere demokrasiye yönelik temel bilgi ve becerilerin öğrencilerine nasıl kazandırılacağı konusunun sınıf düzeylerine göre belirlenmesi ve bu konuların, derslerde uygun yöntem ve tekniklerle işlenmesi konusunda seminer verilebilir, öğretmenler bu konuda eğitilebilir.

Açıklama: Bu çalışmanın bir kısmı Antalya'da düzenlenen 1. Uluslararası Sınırsız Eğitim ve Araştırma Sempozyumunda (24-26 Nisan 2017) sözlü bildiri olarak sunulmuştur.

\section{Kaynaklar}

Beetham, D. ve Boyle, K. (1998). Demokrasinin temelleri 80 soru ve cevap (V. Biçak, Çev.). Ankara: Liberte Yayınları.

Beetham, D. (2006). Demokrasi ve insan hakları. Ankara: Liberte Yayınları. 
Bellamy, R. (1991). Schumpeter and the transformation of capitalism, liberalism and democracy. Government and Opposition, 26(4), 500-519.

Bilgin, N. (2006). Sosyal bilimlerde içerik analizi: Teknikler ve örnek çalışmalar. Ankara: Siyasal Kitabevi.

Cameron, L. (1996). Discourse contextand the development of metaphor in children. Current Issues in Language and Society, 3(1), 48-64.

Çankaya, D. ve Seçkin, O. (2004). Demokratik değerlerin benimsenmesi açısından öğretmen ve öğretmen adaylarının görüsş ve tutumları. Uluslararası Demokrasi Eğitimi Sempozyumu Tam Metin Kitabı (ss. 461-466), 20-21 Mayıs, Çanakkale.

Dewey, J. (2010). Okul ve toplum. (Çev.: H. Avni Başman). Ankara: PegemA.

Dündar, H. (2012). Elementary students' metaphors for democracy. Educational Research and Reviews. 7(24), 509-516.

Engle, S. and Ochoa, A. (1988). Education for democratic citizenship: Decision making in the social studies. New York: Teachers College Press.

Farrel, J. P. (1998). Democracy and education: Who gets to speak and who is listened to? Curriculum Inquary, 28(1), 1-7.

Güder Yağan S. and Yıldırım A. (2014). Okulöncesi öğretmeni adaylarının demokrasiye ilişkin metaforları. Adlyaman Üniversitesi Sosyal Bilimler Enstitüsü Dergisi, 7(16), 151-170.

Harber, C., (2002). Education, democracy and poverty reduction in Africa. Comparative Education, $38(3), 267-276$.

İpek, İ. (2011). İlköğretim 6. ve 7. sinıf Sosyal Bilgiler ders kitaplarındaki vatandaşlık eğitiminin Sosyal Bilgiler öğretim programındaki hedeflere uygunluğu yönünden değerlendirilmesi. Yüksek Lisans Tezi. Balıkesir Üniversitesi, Sosyal Bilimler Enstitüsü, Balıkesir.

Karadağ, E., Baloğlu, N. ve Yalçınkayalar, P. (2006). İlköğretim okulu yöneticilerinin öğretmenler tarafından algılanan demokratik tutumları ile öğretmenlerin demokratik değerleri üzerine ilişkisel bir araştırma. Değerler Ĕ̈itimi Dergisi, 4(12), 65-82.

Kuş, Z., Sönmez, Ö. F. ve Karatekin K. (2011). Okulda yaşam biçimi olarak demokrasi eğitimi. X. Ulusal Sınıf Öğretmenliği Eğitimi Sempozyumu. 5-7 Mayıs, Sivas Sözlü Bildiri.

Kuş, Z. (2012). Illköğretim öğrencilerinin demokrasi algılarının çeşitli değişkenler açısından incelenmesi. Doktora Tezi. Gazi Üniversitesi Eğitim Bilimleri Enstitüsü, Ankara.

Kuş, Z. ve Çetin, T. (2014). İlköğretim öğrencilerinin demokrasi algıları. Kuram ve Uygulamada Eğitim Bilimleri, 14(2), 1-22.

Kuş, Z. ve Tarhan, Ö. (2016). Political education in social studies classrooms: A perspective from Turkey. Journal of Theory and Practice in Education, 12(3), 464-483.

Lipset, S. M. (1986). Siyasal insan. (Çev. Mete Tunçay). Ankara: V Yayınları.

Lakoff, G. ve Johnson, M. (2010). Metaforlar hayat, anlam ve dil. (Çev: Gökhan Yavuz Demir). İstanbul: Paradigma Yayınc1lk.

Miles, M. B. and Huberman, A. M. (1994). Qualitative data analysis. Thousand Oaks, CA: Sage Publication. 
Maitles. H. and Gilrchrist I. (2006). Never too young to learn democracy: A case study of a democratic approach to learning in a religious and moral education secondary class in the west of Scotland. Educational Review, 58(1), 67-85.

Patton, M. Q. (2002). Qualitative research \& evaluation methods. Thousand Oaks, CA: Sage Publication.

Palmquist, R. A. (2001). Cognitive style and users' metaphors forthe web: An exploratory study. The Journal Of Academic Librarianship, 27(1), 24-32.

Richardson, V. (2003). Preservice teachers' beliefs. In J. Raths and A. C. McAninch (Eds.), Teacher beliefs and classroom performance: The impact of teacher education (p. 1-22). Greenwich, CT: Information Age Publishing.

Schmitt, R. (2005). Systematic metaphor analysis as a method of qualitative research. The Qualitative Report, 10(2), 358-394.

Sinatra, G., I. Beck and M. McKeown. (1992). A longitudinal characterization of young students knowledge of their country's government. American Educational Research Journal, 29, 63361.

Soydaş, S. ve Güven, B. (2009). Öğrencilerin Hayat Bilgisi dersinde demokrasi kavramı ile ilgili oluşturdukları metaforların incelenmesi. İçinde Kıncal, R. (Ed.), International symposium on democracy and democracy education in Europe proceedings (ss. 64-80). Ankara: Nobel Yayın Dağıtım.

Tarhan, Ö. (2016). Eğitimin siyasi temelleri. İçinde Susar Kırmızı, F. ve Duban, N. (Ed.), Eğitim bilimine giriş (ss. 137-166). Ankara: Anı Yayıncılık.

Taşkesen, A. (2005). Demokrasi ve demokrasi kültürü. İçinde T. Temiz (Ed.), Vatandaşlık bilgisi (ss. 99-119). Elmaziye, İstanbul: Lisans Yayınc1lık.

Touraine, A. (1997). What is democracy? Boulder, Colorado: Westview Press.

O'Hair, M.J., McLaughlin, H.J. and Reitzug, U.C., (2000). Foundations of democratic education. Orlando: Harcourt College Publishers.

Öncül, R. (2000). Eğitim ve ögretim bilimleri sözlüğü. İstanbul: Milli Eğitim Basımevi.

Westheimer, J. and Kahne, J. (2003). Teaching democracy: What schools need to do. Phi Delta Kappan, 85(1), 34-67.

Yagan, S. (2010). Bağımsız anaokullarında görev yapan öğretmenlerin ve okul müdürlerinin demokrasi ve demokrasi eğitimine yönelik görüşleri: Eskişehir il örneği. Yüksek lisans tezi. Anadolu Üniversitesi Eğitim Bilimleri Enstitüsü, Eskişehir.

Yıldırım, A. ve Şimşek, H. (2006). Sosyal bilimlerde nitel araştırma yöntemleri. Ankara: Seçkin Yayınları.

Yetek, Y. (2003). İlköğretim okulu yöneticilerinin demokratik değerlere sahip olma düzeyi. Yüksek lisans tezi. Çanakkale 18 Mart Üniversitesi Sosyal Bilimler Enstitüsü, Çanakkale.

Yüce, G. S. ve Demir, Ö. (2011). Polis adaylarının “demokrasi” kavramına ilişkin algılarının metaforlar aracılığıla incelenmesi. Polis Bilimleri Dergisi, 13(2), 147-178. 


\section{Extended Abstract}

\section{Introduction}

Democracy is more than the election of rulers by the people. In countries where democracy exists, individuals know that they are not privileged and have equal rights to all citizens in all matters. Management is structured according to similarities, not differences between people. Today, democracy is seen as an important value not only in the administration of the state but also in all areas of life. In the family, in the classroom, in the workplace, in short, all areas of social life are needed. The aim of this study is to determine the metaphoric perceptions of social studies teachers working in secondary schools on the concept of democracy. In this research, it was tried to determine the metaphors that social studies teachers have about the concept of democracy and under which conceptual categories these metaphors are collected in terms of common characteristics.

\section{Method of Research}

Phenomenology, one of the qualitative research methods, was adopted in the study. Metaphors and themes were determined and content analysis was used. The form prepared by the researchers was used to obtain the data. The participants Democracy ......... Because ......... These completions, which the participants wrote in their own handwriting, were used as the main data source in the research. Maximum diversity sampling method was used to determine the study group. A total of 143 social studies teachers from 36 secondary schools selected randomly from the lower, middle and upper socio-economic schools participated in the study.

Content analysis and categorical analysis were used in the analysis of the data. Content analysis enables discovery of discursive content rather than visible, easily captured, exhibited and perceived content at first sight. The categorical analysis technique can be described as dividing a particular message into units and then grouping these units into categories according to specific criteria. In the formation of conceptual categories, the findings of both researchers were compared and then the consistency level was tried to be determined. Miles and Huberman's (1994, p. 64) formula (Reliability $=$ consensus / consensus + disagreement $X 100)$ was found to be $94 \%$. According to Miles and Huberman (1994), the consistency of $90 \%$ and more in the comparison of the classifications made by the two researchers increases the reliability of the study.

\section{Results}

The metaphors and themes that emerge on the simulations of the participants are as follows. 1The Necessity of Life (13 people, 9.09\%): In this theme, the necessity and importance of democracy in social terms are expressed through the metaphors made for the objects and situations necessary for the survival of people. 2- Overcoming Obstacles (5 people, $3.49 \%$ ): The metaphors of this theme emphasized the difficult situations to be realized and expressed the difficulty of the establishment of democracy in society. 3- Ideal Democracy (8 people, $5.59 \%$ ): Democracy should be brought together with the society within the scope of certain measures. Freedom is not to do everything you want. 4Sacrifice and Empathy (21 people, $14.68 \%$ ): Metaphors created within the scope of this theme revealed the necessities of democracy such as respect and tolerance. 5- The Benefits of Democracy to the Society (7 persons, $4.89 \%)$ : In this metaphor, the values that democracy adds to society such as peace and pluralism are emphasized. 6- Accepting Differences (25 people, $17.48 \%$ ): The positive and facilitating effects of democracy on human relations were expressed in the metaphors of this theme. 7Equality of Democracy (26 people, $18.18 \%$ ): In these metaphors, how effective democracy is in achieving equality among people is stated. 8- The Libertarian Side of Democracy (9\%, $6.23 \%$ ): In this theme, it is emphasized that people in democratic societies can express their differences easily and freely. 9- Democracy and Social Peace (10 people $8.39 \%$ ): In the metaphors within the scope of this theme, the effective role of democracy in ensuring the peace and peace environment in the society has been expressed. 10- Development Process of Democracy (10 persons, $6.99 \%$ ): The metaphors created emphasize that the democratic way of life will not occur in a single moment, it takes time and is a 
difficult and laborious process. 11- Unusual analogies (6 people, $4.19 \%)$ : The participants expressed ideas in these metaphors that were quite creative and not known.

\section{Conclusion, Discussion and Suggestions}

As a result of the content analysis of the data obtained in this study, which aims to determine the perspectives of social studies teachers in terms of democracy through metaphors, it is seen that 95 metaphors ( $f=66.43$ ) are collected in 11 different themes. The themes in question are the non of life, overcoming obstacles, the understanding of ideal democracy, difference and empathy, accepting differences, accepting differences, the egalitarian side of democracy, the libertarian side of democracy, democracy and social peace, the development process of democracy and extraordinary parables. The metaphors obtained as a result of the research are strong clues to determine how the concept of democracy is perceived by social studies teachers. It is very important that teacher education programs include practical applications that will enable the use of this information instead of loading theoretical information about democracy education. According to the findings of the study, the most metaphors created by social studies teachers were included in the themes of egalitarian side of democracy (14\%) and accepting differences $(11.57 \%)$, while the least metaphor developed themes were the libertarian side of democracy $(5,26 \%)$. It is remarkable that the metaphors produced under the title of democracy, which are egalitarian and accepting differences, contain the concepts of diversity, understanding, respect, balance, justice, patience, difference, necessity, importance and empathy. From these statements, it is seen that teachers perceive the concept of democracy as an indispensable element for the welfare and peace of society and it is necessary to implement the concepts emphasized in the reasons of the metaphors produced for the formation of a democratic environment. 